\title{
Protein Dynamics in Whole Body and in Splanchnic and Leg Tissues in Type I Diabetic Patients
}

\author{
K. Sreekumaran Nair, ${ }^{\star \ddagger}$ G. Charles Ford, ${ }^{\star \star}$ Karin Ekberg, Eva Fernqvist-Forbes, ${ }^{\boldsymbol{\S}}$ and John Wahren ${ }^{\mathbf{s}}$ \\ *University of Vermont College of Medicine, Department of Medicine, Burlington, Vermont 05405; ${ }^{\ddagger}$ Endocrinology Division, \\ Mayo Clinic, Rochester, Minnesota 55905; and ${ }^{8}$ Clinical Physiology, Karolinska Institute, Stockholm, Sweden
}

\begin{abstract}
To elucidate the mechanism of insulin's anticatabolic effect in humans, protein dynamics were evaluated in the wholebody, splanchnic, and leg tissues in six $\mathrm{C}$-peptide-negative type $I$ diabetic male patients in the insulin-deprived and insulin-treated states using two separate amino acid models (leucine and phenylalanine). L- $\left(1-{ }^{13} \mathrm{C},{ }^{15} \mathrm{~N}\right)$ leucine, $\mathrm{L}$-( ring${ }^{2} \mathrm{H}_{5}$ ) phenylalanine, and $\mathrm{L}$ - $\left(\right.$ ring- $\left.{ }^{2} \mathrm{H}_{2}\right)$ tyrosine were infused intravenously, and isotopic enrichments of $\left[1-{ }^{13} \mathrm{C},{ }^{15} \mathrm{~N}\right]$. leucine, $\left({ }^{13} \mathrm{C}\right)$ leucine, $\left({ }^{13} \mathrm{C}\right)$ ketoisocaproate, $\left({ }^{2} \mathrm{H}_{5}\right)$ phenylalanine, $\left[{ }^{2} \mathrm{H}_{4}\right]$ tyrosine, $\left({ }^{2} \mathrm{H}_{2}\right)$ tyrosine, and ${ }^{13} \mathrm{CO}_{2}$ were measured in arterial, hepatic vein, and femoral vein samples. Whole-body leucine flux, phenylalanine flux, and tyrosine flux were decreased $(<0.01)$ by insulin treatment, indicating an inhibition of protein breakdown. Moreover, insulin decreased $(<0.05)$ the rates of leucine oxidation and leucine transamination $(P<0.01)$, but the percent rate of ketoisocaproate oxidation was increased by insulin $(P<0.01)$. Insulin also reduced $(<0.01)$ whole-body protein synthesis estimated from both the leucine model (nonoxidative leucine disposal) and the phenylalanine model (disposal of phenylalanine not accounted by its conversion to tyrosine). Regional studies demonstrated that changes in whole body protein breakdown are accounted for by changes in both splanchnic and leg tissues. The changes in whole-body protein synthesis were not associated with changes in skeletal muscle (leg) protein synthesis but could be accounted for by the splanchnic region. We conclude that though insulin decreases whole-body protein breakdown in patients with type I diabetes by inhibition of protein breakdown in splanchnic and leg tissues, it selectively decreases protein synthesis in splanchnic tissues, which accounted for the observed decrease in whole-body protein synthesis. Insulin also augmented anabolism by decreasing leucine transamination. (J. Clin. Invest. 1995. 95:2926-2937.) Key words: type I diabetes • protein synthesis • protein breakdown • splanchnic • muscle
\end{abstract}

\section{Introduction}

Patients with type I diabetes (IDDM) ${ }^{1}$ typically were cachectic during the preinsulin era (1). This changed after the introduc-

Address correspondence to Dr. K. S. Nair, Mayo Clinic, Endocrine Research Unit, 5-164 West Joseph, Rochester, MN 55905. Phone: 507255-6515; FAX: 507-255-4828.

Received for publication 26 August 1994 and in revised form 27 December 1994

1. Abbreviations used in this paper: IDDM, type I (insulin-dependent) diabetes; KIC, ketoisocaproate.

The Journal of Clinical Investigation, Inc.

Volume 95, June 1995, 2926-2937 tion of insulin therapy. Insulin treatment decreased urinary nitrogen loss (2), increased lean body mass (3), and decreased concentrations of circulating amino acids, especially those of branched amino acids $(4,5)$. Insulin also controlled the energy expenditure to normal (6). These are generally described as insulin's anticatabolic effect. Numerous investigators had sought to understand the mechanism of insulin's anticatabolic effect on protein (7-24). These studies are reviewed elsewhere (18). A common conclusion of these studies is that insulin decreases whole-body protein breakdown in the fasted state. This insulin effect has been shown to be partially due to the effect on skeletal muscle $(20,21)$, although this is contradicted by some studies $(13,22-24)$. Insulin's effect on protein breakdown in other regions, such as splanchnic tissues, has not been investigated. The splanchnic region is a major site of protein metabolism (25), but its precise role remains to be clearly defined.

Insulin also has been shown to reduce the rate of leucine oxidation (8-18), although it is unclear whether this is related to changes in leucine transamination or due to increased oxidation of ketoisocaproate (KIC), the transamination product of leucine. Unlike the inhibitory effect of insulin on protein breakdown and leucine oxidation, insulin's effect on protein synthesis in the fasted state remains controversial.

It was initially reported that in the insulin-deprived state, IDDM patients have increased nonoxidative leucine disposal, indicating an increased whole-body protein synthesis $(7,8)$. Insulin infusion in these patients decreased whole-body protein synthesis $(10,12-16)$. These results were in conflict with the existing view that insulin promotes protein synthesis $(26,27)$. This view was based on strong in vitro evidence documenting insulin's stimulatory effect on protein synthesis $(26,27)$. The in vitro data are supported by studies in growing rats rendered diabetic by streptozotocin $(28,29)$. However, unlike the growing rats, human studies have been performed in adult diabetic patients. These studies consistently show either a significant increase $(7,8,10-16)$ or slight but not statistically significant increase of whole-body protein synthesis in insulin-deprived IDDM patients $(9,17)$. Additional studies in IDDM patients $(8,15,17,18)$ and in normal subjects $(20-22)$ demonstrated that these changes in protein synthesis do not occur in the muscle protein. It was proposed that in the insulin-deprived state, increased flux of amino acids from protein breakdown increases protein synthesis in relatively insulin-insensitive tissues, such as gut and liver (18). We tested the hypothesis that increased whole-body protein synthesis occurs in insulindeprived IDDM patients because of an increase in the synthesis rate of proteins in insulin-insensitive tissues, such as in gut and liver. Consequently, we studied IDDM patients to determine the effect of insulin treatment on protein synthesis and degradation in the splanchnic region and determined whole-body and skeletal muscle protein dynamics. 
Table I. Characteristics of the Diabetic Patients $(n=6)$

\begin{tabular}{|c|c|c|c|c|c|c|c|c|}
\hline Subject & Age & Height & Weight & Body mass index & HbAlc & $\begin{array}{c}\text { Duration } \\
\text { of diabetes }\end{array}$ & C-peptide level & Insulin requirement \\
\hline & $y r$ & $m$ & $k g$ & $w / H^{2}=k g / m^{2}$ & $\%$ & $y r$ & nmolliter & units \\
\hline 1 & 25 & 1.78 & 74 & 23.4 & $6.8(6.4)$ & 12 & 0.07 & 46 \\
\hline 2 & 27 & 1.72 & 69 & 23.3 & $7.1(6.4)$ & 14 & 0.04 & 60 \\
\hline 3 & 31 & 1.81 & 65 & 19.9 & $6.8(6.1)$ & 29 & $<0.04$ & 60 \\
\hline 4 & 35 & 1.85 & 71 & 20.8 & $5.9(5.3)$ & 20 & 0.06 & 44 \\
\hline 5 & 26 & 1.74 & 62 & 20.5 & $6.3(6.1)$ & 18 & 0.10 & 50 \\
\hline 6 & 31 & 1.74 & 72 & 23.8 & $7.6(6.7)$ & 17 & $<0.04$ & 68 \\
\hline Mean \pm SEM & $29.2 \pm 1.6$ & $1.77 \pm 0.02$ & $68.8 \pm 1.9$ & $22.95 \pm 0.71$ & $\begin{array}{c}6.8 \pm 0.3 \\
(6.2 \pm 0.2)\end{array}$ & $18.3 \pm 2.4$ & $0.06 \pm 0.01$ & $54.7 \pm 3.9$ \\
\hline
\end{tabular}

* Reported HbAlc values indicate insulin deprivation; parentheses indicate insulin treatment.

\section{Methods}

\section{Materials and techniques}

$\mathrm{L}-\left(1-{ }^{13} \mathrm{C},{ }^{15} \mathrm{~N}\right)$ leucine (99 atom percent excess), L-(ring- $\left.{ }^{2} \mathrm{H}_{5}\right)$ phenylalanine ( 99 atom percent excess), $\mathrm{L}$-( $\left(\right.$ ring- $\left.{ }^{2} \mathrm{H}_{4}\right)$ tyrosine ( 99 atom percent excess), and $\mathrm{L}-\left(\right.$ ring- $\left.{ }^{2} \mathrm{H}_{2}\right)$ tyrosine ( 99 atom percent excess) were purchased from Cambridge Isotope Laboratories, Inc. (Woburn, MA). The chemical, isotopic, and optical purity of these isotopes was tested before use. Solutions were prepared under sterile precautions and were shown to be bacterial and pyrogen free before use in human subjects.

The protocol was submitted to and approved by the institution ethics committee. The nature, purpose, and possible risks involved in the study were carefully explained to each subject before his informed consent was obtained.

\section{Subjects}

Six male IDDM patients participated in the study. The individual clinical characteristics are given in Table I. Four patients had background retinopathy (microaneurysm), and one had microalbuminuria. All patients had normal serum creatinine values. Except for insulin, the patients had no other medication. All patients were treated with four daily insulin injections (regular insulin before meals and intermediate acting insulin at bedtime). Subjects whose insulin requirements were $>70$ units per day were excluded in order to avoid patients with severe insulin resistance.

\section{Study protocol}

Two separate studies were performed on each subject at 2-3-wk interval. One study was performed in the insulin-deprived state and another in the insulin-treated state. In three subjects, studies in the insulindeprived state were done first, and in the other three patients, studies in the insulin-treated state were done first. The patients were admitted to the hospital on the day before the study. The last subcutaneous injection of regular insulin was given at 6:00 PM. At 9:00 PM in the evening before the study, an intravenous insulin infusion was started to maintain a blood glucose level between 4 and $6 \mathrm{mmol} /$ liter until 7:00 AM in the morning of the study day (insulin treatment). For the other study, saline instead of insulin was infused intravenously from midnight of the day before the study until the end of the study (insulin deprivation). The studies were performed after an overnight fast; ingestion of water was allowed. In the case of the studies performed in the insulintreated state, the insulin dose was adjusted from 7:00 AM every 10$15 \mathrm{~min}$ on the basis of blood glucose values in order to maintain blood glucose at a steady state of $4.4 \pm 0.4 \mathrm{mmol} /$ liter (see Fig. 1).

In both studies, a forearm vein was cannulated for infusions. Catheters were then placed in the brachial artery, femoral artery, femoral vein, and hepatic vein as was previously described $(25,30)$. Hepatic vein catheters were inserted under fluoroscopic guidance, and placement was performed as reported previously (30). The femoral artery line was used for infusing indocyanine green dye at a rate of $0.6 \mathrm{mg} / \mathrm{min}$ in order to measure blood flow in the leg and splanchnic regions using indicator dye dilution techniques $(30,31)$. Branchial artery, femoral vein, and hepatic vein lines were used to collect blood samples.

After taking triplicate baseline breath samples and blood samples from arterial, femoral vein, and hepatic vein lines, priming doses of $\mathrm{L}-\left(1-{ }^{13} \mathrm{C},{ }^{15} \mathrm{~N}\right)$ leucine $(6.8 \mu \mathrm{mol} / \mathrm{kg}), \mathrm{L}-\left(\right.$ ring- $\left.{ }^{2} \mathrm{H}_{5}\right)$ phenylalanine $(4.6$ $\mu \mathrm{mol} / \mathrm{kg}), \mathrm{L}-\left(\right.$ ring- $\left.{ }^{2} \mathrm{H}_{2}\right)$ tyrosine $(3.5 \mu \mathrm{mol} / \mathrm{kg}), \mathrm{L}-\left(\right.$ ring- $\left.{ }^{2} \mathrm{H}_{4}\right)$ tyrosine $(1.5 \mu \mathrm{mol} / \mathrm{kg})$, and $\left({ }^{13} \mathrm{C}\right)$ sodium bicarbonate $(0.2 \mathrm{mg} / \mathrm{kg})$ were given in order to prime the respective pools for achieving an early plateau. A continuous infusion of $\mathrm{L}-\left(1-{ }^{13} \mathrm{C},{ }^{15} \mathrm{~N}\right)$ leucine $(7.5 \mu \mathrm{mol} / \mathrm{kg} / \mathrm{h}), \mathrm{L}-$ $\left({ }^{2} \mathrm{H}_{5}\right)$ phenylalanine $(4.6 \mu \mathrm{mol} / \mathrm{kg} / \mathrm{h})$, and $\mathrm{L}-\left({ }^{2} \mathrm{H}_{2}\right)$ tyrosine $(3.5 \mathrm{~mol} /$ $\mathrm{kg} / \mathrm{h}$ ) was started and maintained for $4 \mathrm{~h}$.

Blood samples from the femoral artery, femoral vein, and hepatic vein and breath samples were collected at the baseline and at 170, 175, $180,200,205,210,230,235$, and $240 \mathrm{~min}$. Indirect calorimetry was performed on three separate occasions between 170 and $240 \mathrm{~min}$ to measure $\mathrm{CO}_{2}$ production and $\mathrm{O}_{2}$ consumption. The mean of these three measurements was taken as $V_{\mathrm{CO}_{2}}$ during that period. The study was stopped after collecting samples at $240 \mathrm{~min}$. Arterial and venous lines were withdrawn, pressure was applied for $20 \mathrm{~min}$ over the arterial and venous puncture sites, and a pressure bandage was applied over the arterial puncture site for $6 \mathrm{~h}$.

\section{Analysis of samples}

Plasma and gas isotopic enrichments. The enrichment levels of [1$\left.{ }^{13} \mathrm{C},{ }^{15} \mathrm{~N}\right]$ and total $\left[{ }^{13} \mathrm{C}\right]$ leucine in plasma from the infusion of $\mathrm{L}-[1-$ $\left.{ }^{13} \mathrm{C},{ }^{15} \mathrm{~N}\right]$ leucine were determined using an HP5988 gas chromatograph/ mass spectrometer by multiple ion monitoring under positive ion methane chemical ionization conditions. Fragment ions from heptofluorobutyryl isobutyl ester derivative, at $\mathrm{m} / \mathrm{z} 283 / 282$ and $\mathrm{m} / \mathrm{z} 384 / 385 / 386$, were monitored to determine the ${ }^{15} \mathrm{~N}$ - and mono/di-labeled species, respectively $(32,34)$. Leucine concentration was measured using norleucine as an internal standard (7).

$\left({ }^{2} \mathrm{H}_{5}\right)$ phenylalanine, $\left({ }^{2} \mathrm{H}_{2}\right)$ tyrosine, and $\left({ }^{2} \mathrm{H}_{4}\right)$ tyrosine were measured as their $t$-butyldimethylsilyl ether derivatives under electron ionization conditions, by monitoring the $[\mathrm{M}-57]^{+}$fragment ions at $\mathrm{m} / \mathrm{z}$ $341 / 336$ for phenylalanine and $\mathrm{m} / \mathrm{z} 470 / 468 / 466$ for tyrosine. Concentrations of phenylalanine and tyrosine were measured using $\beta$-methylphenylalanine and $\alpha$-methyltyrosine, respectively, as internal standards. $\left({ }^{13} \mathrm{C}\right) \mathrm{KIC}$ in plasma was determined as its quinoxalinol-TMS derivative under electron ionization conditions using an HP5971A gas chromatograph/mass spectrometer, and the enrichment was monitored using ions $\mathrm{m} / \mathrm{z}$ 233/232 (33-35). KIC concentration was measured using ketovaleric acid as an internal standard.

Blood ${ }^{13} \mathrm{CO}_{2}$ enrichment and ${ }^{13} \mathrm{CO}_{2}$ in the breath samples in an isotope ratio mass spectrometry were as previously described (36). 
Substrate concentration. Plasma concentrations of amino acids were determined by an HPLC system (HP 1090 series 2 HPLC, 1046 fluorescence detector and cooling system) with precolumn $O$-phthalaldehyde derivatization (37). Glucose was analyzed by an enzymatic technique using a glucose analyzer (Beckman Instr., Inc., Fullerton, CA); lactate (38), free fatty acid (39), and $\beta$-hydroxybutyrate ( 40$)$ were measured as previously described.

Hormonal assays. Plasma concentrations of free insulin (41), glucagon (42), growth hormone (43), IGF-I (44), IGF-I-binding protein1 (45) epi- and norepinephrine (46), and cortisol were measured by a radioimmunoassay technique.

Calculations. For all calculations of amino acid kinetics, mean values of isotopic enrichments at all nine time points were used.

\section{Leucine kinetics}

Leucine carbon flux $\left(Q_{c}\right)$ and leucine nitrogen fluxes $\left(Q_{n}\right)$ were measured by tracer dilution techniques as previously described $(7,32)$. $Q_{\text {(flux) }}=i\left[\left(E_{\mathrm{i}} / E_{\mathrm{p}}\right)-1\right]$, in which $i$ is the rate of tracer infusion of $(\mu \mathrm{mol} / \mathrm{kg} / \mathrm{h})$, and $E_{\mathrm{i}}$ and $E_{\mathrm{p}}$ are enrichment of the tracer infused and plasma enrichment of the tracer at isotopic plateau, respectively. Leucine oxidation (C) was measured using $\left({ }^{13} \mathrm{C}\right) \mathrm{KIC}$ as the precursor pool (47). Nonoxidative leucine flux, an estimation of leucine incorporated into protein (protein synthesis), was computed by subtracting leucine oxidation from leucine carbon flux, since the leucine carboxyl group is either irreversibly lost as $\mathrm{CO}_{2}$ or incorporated into protein. For calculating $Q_{c}$, plasma $\left({ }^{13} \mathrm{C}\right) \mathrm{KIC}$ was used, and for $Q_{\mathrm{n}},\left[1-{ }^{13} \mathrm{C},{ }^{15} \mathrm{~N}\right]$ leucine isotopic enrichment at plateau was used. The theoretical aspects of this model are discussed elsewhere $(32,36)$.

Transamination (deamination) of leucine into $\mathrm{KIC}\left(X_{\mathrm{o}}\right)$ and retransamination (reamination) of KIC back to leucine $\left(X_{n}\right)$ are calculated as follows: $Q_{\mathrm{n}}-Q_{\mathrm{c}}=X_{\mathrm{n}}=X_{\mathrm{o}}-C$. In this equation $Q_{\mathrm{n}}, Q_{\mathrm{c}}$, and $C$ are all measured, and therefore $X_{\mathrm{n}}$ and $X_{\mathrm{o}}$ are estimated.

Leg and splanchnic region. Leucine kinetics, leucine appearance from protein breakdown (protein to leucine), the component of leucine disappearance not accounted for by leucine oxidation, and leucine transamination (leucine to protein or protein synthesis) in the leg and splanchnic region were measured using the equations previously described by Cheng et al. (36).

\section{Phenylalanine kinetics}

Phenylalanine is not oxidized or transaminated in the periphery but is degraded in the liver through tyrosine $(20,21,48-50)$. It is therefore assumed that in the splanchnic region, phenylalanine is either converted to tyrosine or incorporated into protein. In leg tissues, the only fate of phenylalanine is its incorporation into protein.

Whole body. For whole body measurements of phenylalanine kinetics, the equations described by Thompson et al. (34) were used. Phenylalanine flux $\left(Q_{\mathrm{p}}\right)$ and tyrosine flux $\left(Q_{\mathrm{T}}\right)$ were calculated by isotope dilution in the same way leucine flux was calculated. The rate of phenylalanine conversion to tyrosine $\left(I_{\mathrm{PT}}\right)$ was calculated as follows:

$I_{\mathrm{PT}}=Q_{\mathrm{T}} \times \frac{\left[{ }^{2} \mathrm{H}_{4}\right] \mathrm{Tyr}_{\mathrm{Ei}}}{\left[{ }^{2} \mathrm{H}_{5}\right] \mathrm{Phe}_{\mathrm{Ei}}} \times \frac{Q_{\mathrm{P}}}{\left[I_{\mathrm{P}}+Q_{\mathrm{P}}\right]}$

where $\left[{ }^{2} \mathrm{H}_{4}\right] \mathrm{Tyr}_{\mathrm{Ei}}$ and $\left[{ }^{2} \mathrm{H}_{5}\right] \mathrm{Phe}_{\mathrm{Ei}}$ are the isotopic enrichments of the respective tracers in plasma, and $I_{P}$ is the infusion rate of $\left({ }^{2} \mathrm{H}_{5}\right)$ phenylalanine $(\mu \mathrm{mol} / \mathrm{kg} / \mathrm{h})$.

Phenylalanine incorporation into protein $\left(S_{\mathrm{P}}\right)$ for whole body is calculated by simply subtracting $I_{\mathrm{PT}}$ from $Q_{\mathrm{P}}$, since phenylalanine is irreversibly lost either by its degradative pathway via its conversion into tyrosine or by incorporation into protein $(21,51)$.

Splanchnic region. Phenylalanine appearance rate $\left(R_{\mathrm{P}}\right)$ in the postabsorptive state can be calculated by the following equation (the details of its derivation have been previously described for an arterio-venous study across leg [51]):

$R_{\mathrm{P}}=\left[\left(\frac{\left[{ }^{2} \mathrm{H}_{5}\right] \mathrm{Phe}_{\mathrm{EA}}}{\left[{ }^{2} \mathrm{H}_{5}\right] \mathrm{Phe}_{\mathrm{EV}}}\right)-1\right] \times \mathrm{Phe}_{\mathrm{A}} \times F$ where $\left[{ }^{2} \mathrm{H}_{5}\right] \mathrm{Phe}_{\mathrm{EA}}$ and $\left[{ }^{2} \mathrm{H}_{5}\right] \mathrm{Phe}_{\mathrm{EV}}$ represent isotopic enrichments on the arterial and venous sides, respectively, $F$ is plasma flow, and $\mathrm{Phe}_{\mathrm{A}}$ is the phenylalanine concentration on the arterial side.

In these equations it is assumed that phenylalanine is not directly oxidized in the splanchnic region but is degraded via tyrosine, and its only degradative pathway is via its conversion into tyrosine. The precursor pool for protein synthesis and phenylalanine conversion to tyrosine are assumed to be represented by hepatic vein amino acid enrichment. Since phenylalanine entering the splanchnic bed has only two fatesincorporation into protein and conversion into tyrosine-at steady state, the following is true:

$S_{\mathrm{P}}+I_{\mathrm{PT}}=R_{\mathrm{P}}+\left(\mathrm{Phe}_{\mathrm{A}}-\mathrm{Phe}_{\mathrm{V}}\right) \times F$

in which $S_{\mathrm{p}}$ is phenylalanine incorporation into protein (or protein synthesis), $I_{\mathrm{PT}}$ is phenylalanine conversion to tyrosine, $\mathrm{Phe}_{\mathrm{A}}$ and $\mathrm{Phe}_{\mathrm{V}}$ are phenylalanine concentrations on the arterial and venous sides, respectively, and $F$ is plasma flow. The dilution of $\left[{ }^{2} \mathrm{H}_{4}\right]$ tyrosine occurs because of protein breakdown and conversion of phenylalanine to tyrosine. Thus, in a steady state, the following is true:

$R_{\mathrm{T}}+I_{\mathrm{PT}}=\left(\frac{\left[{ }^{2} \mathrm{H}_{2}\right] \mathrm{Tyr}_{\mathrm{EA}}}{\left[{ }^{2} \mathrm{H}_{2}\right] \mathrm{Tyr}_{\mathrm{EV}}}-1\right) \times \mathrm{Tyr}_{\mathrm{A}} \times F$

$R_{\mathrm{T}}$ is tyrosine appearance from protein breakdown, and $\left[{ }^{2} \mathrm{H}_{2}\right] \mathrm{Tyr}_{\mathrm{EA}}$ and $\left[{ }^{2} \mathrm{H}_{2}\right] \mathrm{Tyr}_{\mathrm{EV}}$ are isotopic enrichments of $\left[{ }^{2} \mathrm{H}_{2}\right]$ tyrosine on the arterial and venous sides, respectively. $\operatorname{Tyr}_{\mathrm{A}}$ is tyrosine concentration on the arterial side. This equation is similar to the equation for $R_{\mathrm{p}}(51)$. By simple isotope balance, the following equation can be derived:

$\left[{ }^{2} \mathrm{H}_{2}\right] \mathrm{Tyr}_{\mathrm{EA}} \times \mathrm{Tyr}_{\mathrm{A}} \times F$

$=\left[{ }^{2} \mathrm{H}_{2}\right] \mathrm{Tyr}_{\mathrm{EV}} \times D_{\mathrm{T}}+\left[{ }^{2} \mathrm{H}_{2}\right] \mathrm{Tyr}_{\mathrm{EV}} \times \mathrm{Tyr}_{\mathrm{V}} \times F$

in which $D_{\mathrm{T}}$ is the tyrosine disposal rate.

$\left[{ }^{2} \mathrm{H}_{4}\right] \mathrm{Tyr}_{\mathrm{EA}} \times \mathrm{Tyr}_{\mathrm{A}} \times F+\left[{ }^{2} \mathrm{H}_{5}\right] \mathrm{Phe}_{\mathrm{EV}} \times I_{\mathrm{PT}}$

$=\left[{ }^{2} \mathrm{H}_{4}\right] \mathrm{Tyr}_{\mathrm{EV}}+\mathrm{Tyr}_{\mathrm{V}} \times D_{\mathrm{T}}+\left[{ }^{2} \mathrm{H}_{4}\right] \mathrm{Tyr}_{\mathrm{EV}}+\mathrm{Tyr}_{\mathrm{V}} \times F$

Rearranging Eq. 5 and solving for the rate of disappearance of tyrosine $\left(D_{\mathrm{T}}\right)$, we can derive Eq. 7:

$D_{\mathrm{T}}=\left(\frac{\left[{ }^{2} \mathrm{H}_{2}\right] \mathrm{Tyr}_{\mathrm{EA}}}{\left[{ }^{2} \mathrm{H}_{2}\right] \mathrm{Tyr}_{\mathrm{EV}}} \times \operatorname{Tyr}_{\mathrm{A}}-\mathrm{Tyr}_{\mathrm{V}}\right) \times F$

By substituting Eq. 7 (i.e., $D_{\mathrm{T}}$ ) into Eq. 6, the following equation can be mathematically derived:

$\left[{ }^{2} \mathrm{H}_{4}\right] \mathrm{Tyr}_{\mathrm{EA}} \times \mathrm{Tyr}_{\mathrm{A}} \times F+\left[{ }^{2} \mathrm{H}_{5}\right] \mathrm{Phe}_{\mathrm{EV}} \times I_{\mathrm{PT}}$

$=\left[{ }^{2} \mathrm{H}_{4}\right] \operatorname{Tyr}_{\mathrm{EV}} \times\left(\frac{\left[{ }^{2} \mathrm{H}_{2}\right] \mathrm{Tyr}_{\mathrm{EA}}}{\left[{ }^{2} \mathrm{H}_{2}\right] \mathrm{Tyr}_{\mathrm{EV}}} \times \mathrm{Tyr}_{\mathrm{A}}-\mathrm{Tyr}_{\mathrm{V}}\right)$

$\times F+\left[{ }^{2} \mathrm{H}_{4}\right] \mathrm{Tyr}_{\mathrm{Ev}} \times \mathrm{Tyr}_{\mathrm{v}} \times F$

Simplifying Eq. 8 we can get Eq. 9:

$\left[{ }^{2} \mathrm{H}_{4}\right] \mathrm{Tyr}_{\mathrm{EA}} \times \mathrm{Tyr}_{\mathrm{A}} \times F+\left[{ }^{2} \mathrm{H}_{5}\right] \mathrm{Phe}_{\mathrm{Ev}} \times I_{\mathrm{PT}}$

$=\left[{ }^{2} \mathrm{H}_{4}\right] \mathrm{Tyr}_{\mathrm{EV}} \times\left(\frac{\left[{ }^{2} \mathrm{H}_{2}\right] \mathrm{Tyr}_{\mathrm{EA}}}{\left[{ }^{2} \mathrm{H}_{2}\right] \mathrm{Tyr}_{\mathrm{EV}}}\right) \times \operatorname{Tyr}_{\mathrm{A}} \times F$

$I_{\mathrm{PT}}$ can be solved from Eq. 9:

$I_{\mathrm{PT}}=\left[\left(\frac{\left[{ }^{2} \mathrm{H}_{2}\right] \mathrm{Tyr}_{\mathrm{EA}}}{\left[{ }^{2} \mathrm{H}_{2}\right] \mathrm{Tyr}_{\mathrm{EV}}}\right) \times \frac{\left[{ }^{2} \mathrm{H}_{4}\right] \mathrm{Tyr}_{\mathrm{EV}}}{\left[{ }^{2} \mathrm{H}_{5}\right] \mathrm{Phe}_{\mathrm{EV}}}-\frac{\left[{ }^{2} \mathrm{H}_{4}\right] \mathrm{Tyr}_{\mathrm{EA}}}{\left[{ }^{2} \mathrm{H}_{5}\right] \mathrm{Phe}_{\mathrm{EV}}}\right]$

$\times \operatorname{Tyr}_{\mathrm{A}} \times F$

Using Eqs. 3 and 10, $S_{\mathrm{p}}$ can be determined.

\section{Statistics}

All values are expressed as mean \pm SEM. Paired $t$ test was used to compare the single measurements (e.g., amino acid kinetics and amino 

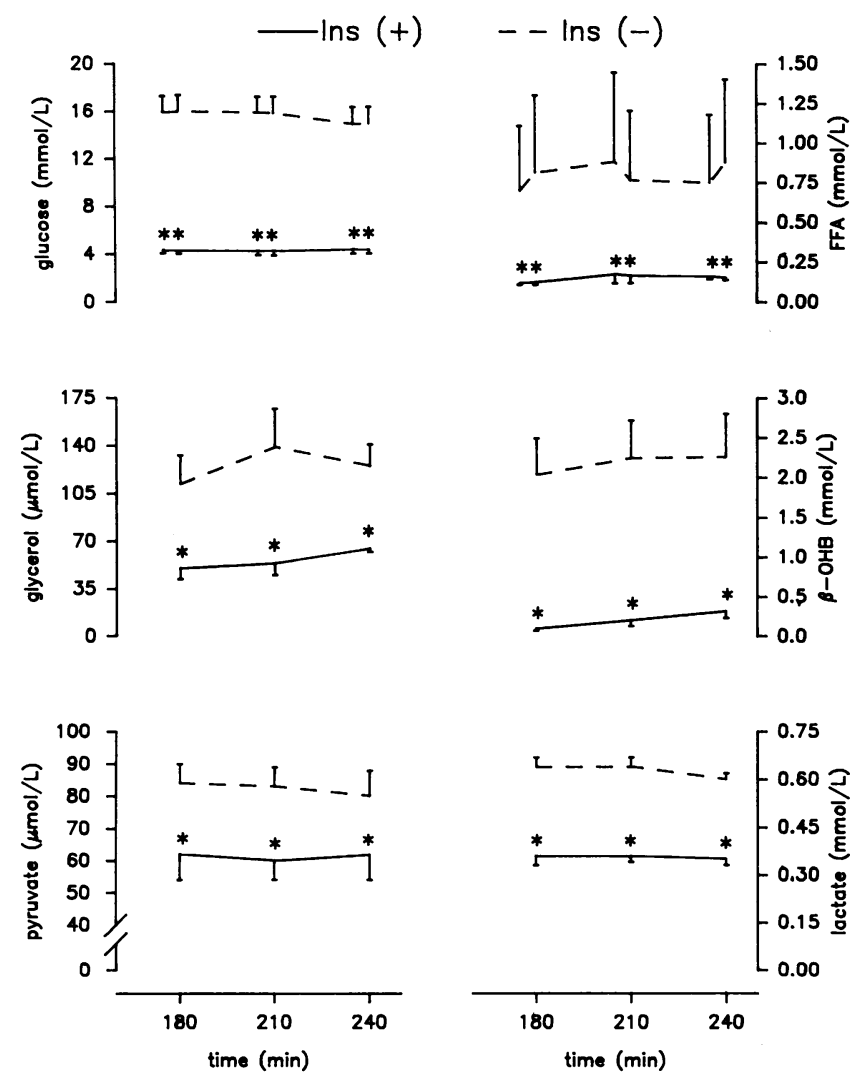

Figure 1. Arterial plasma concentrations of glucose, glycerol, pyruvate, FFA, $\beta$-hydroxybutyrate, and lactate were higher during the last hour of insulin deprivation (dashed line) than during insulin treatment (continuous line $)(P<0.01)$.

acid concentrations) during the insulin-deprived state with those during the insulin-treated state. When multiple measurements were used, ANOVA was used for comparison.

\section{Results}

\section{Blood flow, substrates, and hormones}

Plasma concentrations of glucose, glycerol, free fatty acids, $\beta$ hydroxybutyrate, lactate, and pyruvate during the last $1 \mathrm{~h}$ of the study period are shown in Fig. 1. These substrate concentrations were in a steady state during the last $60 \mathrm{~min}$. Plasma concentrations of glucose, glycerol, lactate, free fatty acids, $\beta$ hydroxybutyrate, and glucose were higher during the insulindeprived state than the insulin-treated state $(P<0.01)$ (Fig. 1). Leg blood flow was higher during insulin deprivation than during insulin treatment $(P<0.01$; Table II $)$. However, splanchnic blood flow did not differ among studies (Table II). Splanchnic and leg exchange (arterial minus venous multiplied by blood flow) of glucose, glycerol, and lactate was higher during the insulin-deprived state than during the insulin-treated state $(P<0.01)$, whereas the difference in glycerol exchange from the leg did not reach statistical significance between the two studies.

Plasma concentrations (mean of three measurements of each hormone) during the last $60 \mathrm{~min}$ are given in Table III. Plasma concentrations of free insulin $(P<0.01)$ and IGF-I $(P<0.05)$ were higher during the insulin-treated state than during the insu-
Table II. Blood and Substrate and Uptakes in Leg $(L)$ and Splanchnic (S) Regions during Insulin-deprived and Insulin-treated States in IDDM Patients

\begin{tabular}{lccl}
\hline \multicolumn{1}{c}{ Measurements } & & Insulin deprived & Insulin treated \\
\hline Blood flow (liters $/ \mathrm{min})$ & $\mathrm{L}$ & $0.44 \pm 0.04$ & $0.31 \pm 0.02^{*}$ \\
& $\mathrm{~S}$ & $1.21 \pm 0.08$ & $1.17 \pm 0.13$ \\
Glucose uptake $(\mathrm{mmol} / \mathrm{min})$ & $\mathrm{L}$ & $0.02 \pm 0.06$ & $0.01 \pm 0.02$ \\
& $\mathrm{~S}$ & $0.99 \pm 0.13$ & $0.59 \pm 0.10^{\ddagger}$ \\
Glycerol uptake $(\mu \mathrm{mol} / \mathrm{min})$ & $\mathrm{L}$ & $26.4 \pm 6.0$ & $11.8 \pm 3.7$ \\
& $\mathrm{~S}$ & $133.8 \pm 23.1$ & $55.5 \pm 11.0^{\ddagger}$ \\
Lactate uptake (mmol/min) & $\mathrm{L}$ & $0.05 \pm 0.02$ & $0.03 \pm 0.01$ \\
& $\mathrm{~S}$ & $0.39 \pm 0.04$ & $0.19 \pm 0.03^{\ddagger}$ \\
& & &
\end{tabular}

* Difference with $P<0.05$. ${ }^{\ddagger}$ Difference with $P<0.01$.

lin-deprived state, whereas glucagon and IGF-I-binding protein-1 plasma concentrations were higher during the insulindeprived state than during the insulin-treated state $(P<0.01)$.

\section{Amino acids}

Plasma concentrations of amino acids are given in Table IV, and amino acid balance (i.e., arterial concentrations minus venous concentrations multiplied by blood flow) are given in Table V. In the case of amino acid balance, we included the measurements using gas chromatograph/mass spectrometer (using internal standards) for leucine, KIC, phenylalanine, and tyrosine because they were used for calculating protein dynamics. Plasma concentrations of histidine, glycine, alanine, phenylalanine, isoleucine, leucine, and valine were reduced by insulin treatment $(P<0.01)$. Whole-blood amino acid concentrations demonstrated a similar trend (data not shown).

Amino acid balance across the splanchnic region and leg are given in Table $\mathrm{V}$. Both plasma amino acid balance and blood amino acid balance were performed. The conclusions were the same, and therefore only plasma balance is given in Table V. Balance across the leg of aspartate, serine, histidine, glycine, threonine, alanine, tyrosine, methionine, phenylalanine, isoleucine, leucine, lysine, and KIC was significantly higher during insulin deprivation than during insulin treatment, indicating an insulin-induced fall in net amino acid output from the

Table III. Arterial Plasma Hormone Concentrations during the Study Period in Six IDDM Patients (210-240 min - Mean of Three Values in Each Subject)

\begin{tabular}{lcc}
\hline & Insulin treated & Insulin deprived \\
\hline Free insulin $(\mu \mathrm{U} / \mathrm{ml})$ & $12 \pm 2$ & $3 \pm 0^{*}$ \\
Glucagon $(\mathrm{pg} / \mathrm{ml})$ & $72 \pm 11$ & $129 \pm 30^{*}$ \\
Cortisol $(\mathrm{nmol} / \mathrm{liter})$ & $264 \pm 32$ & $426 \pm 120$ \\
Growth hormone $(\mu \mathrm{g} / \mathrm{liter})$ & $14.4 \pm 7.7$ & $11.5 \pm 47$ \\
Norepinephrine $(\mathrm{nmol} / \mathrm{liter})$ & $1.19 \pm 13$ & $1.91 \pm 0.52$ \\
Epinephrine (nmol/liter) & $0.68 \pm 0.11$ & $0.46 \pm 0.09$ \\
IGF-I $(\mu \mathrm{g} / \mathrm{liter})$ & $126 \pm 9$ & $102 \pm 9 *$ \\
IGFBP-1 (ng/ml) & $56 \pm 7$ & $203 \pm 38^{*}$ \\
\end{tabular}

IGFBP-1, IGF-I-binding protein-1. * Different from insulin-treated state $(P<0.01)$. 
Table IV. Plasma Arterial Concentrations (Mean of Three Measurements during the Last 60 min of the Study ( $\mu$ mol/liter)

\begin{tabular}{lcc}
\hline \multicolumn{1}{c}{ Amino acids } & Insulin deprived & Insulin treated \\
\hline Glutamit acid & $48.4 \pm 3.7$ & $69.5 \pm 3.1$ \\
Serine & $113.1 \pm 4.1$ & $128.4 \pm 2.0$ \\
Glutamine & $622.0 \pm 23.1$ & $599.4 \pm 13.7$ \\
Histidine & $95.5 \pm 1.9$ & $86.0 \pm 2.0^{*}$ \\
Glycine & $181.5 \pm 6.8$ & $253.8 \pm 3.9^{*}$ \\
Threonine & $112.7 \pm 6.4$ & $109.7 \pm 4.3$ \\
Alanine & $241.3 \pm 10.1$ & $201.8 \pm 6.5^{*}$ \\
Tyrosine & $65.5 \pm 1.3$ & $60.7 \pm 1.6$ \\
Valine & $449.6 \pm 15.2$ & $215.5 \pm 6.2^{*}$ \\
Phenylalanine & $64.6 \pm 1.4$ & $55.0 \pm 1.1^{*}$ \\
Isoleucine & $156.2 \pm 7.6$ & $48.1 \pm 2.0^{*}$ \\
Leucine & $337.6 \pm 12.6$ & $138.6 \pm 3.7^{*}$ \\
Lysine & $184.8 \pm 7.0$ & $171.6 \pm 4$
\end{tabular}

* Significantly different from the insulin-deprived state $(P<0.01)$.

leg and therefore a net decrease in protein breakdown. Balance across the splanchnic bed of serine, histidine, glycine, threonine, alanine, tyrosine, valine, methionine, phenylalanine, isoleucine, leucine, lysine, and KIC was significantly different between the insulin-deprived and insulin-treated states.

\section{Isotopic plateau}

Plasma isotopic enrichments of $\mathrm{KIC}$ and $\mathrm{CO}_{2}$ leucine are given in Fig. 2, and isotopic enrichments of phenylalanine and tyrosine are given in Fig. 3. Isotopic plateau was achieved during this period, since the slopes of these isotopic enrichments did not differ from 0 . Plasma concentrations of leucine, KIC, phenylalanine, and tyrosine are given in Fig. 4, and they achieved a plateau during the study period because the slopes of these measurements were not significantly different from 0 .

\section{Whole-body protein dynamics}

Leucine kinetics (Fig. 5). Whole-body leucine carbon flux (reflecting whole-body protein breakdown) (125.7 \pm 7.2 vs. $93.7 \pm 3.0 \mu \mathrm{mol} / \mathrm{kg} / \mathrm{h}, P<0.01)$, leucine oxidation $(32.8 \pm 3.9$ vs. $19.7 \pm 2.5 \mu \mathrm{mol} / \mathrm{kg} / \mathrm{h}, P<0.05)$, nonoxidative fraction of leucine flux $(96.8 \pm 4$ vs. $76.5 \pm 3 \mu \mathrm{mol} / \mathrm{kg} / \mathrm{h}, P<0.01)$, leucine $\mathrm{N}$ flux $(301.7 \pm 25.8$ vs. $127.9 \pm 5.5 \mu \mathrm{mol} / \mathrm{kg} / \mathrm{h}, P$ $<0.001$ ), reamination of KIC (KIC to leucine) $(200.1 \pm 24.6$ vs. $38.9 \pm 5.4 \mu \mathrm{mol} / \mathrm{kg} / \mathrm{h}, P<0.001$ ), and deamination of leucine (leucine to $\mathrm{KIC})(232.7 \pm 27.5$ vs. $58.5 \pm 4.6 \mu \mathrm{mol} / \mathrm{kg} / \mathrm{h}$, $P<0.001)$ were all higher during insulin deprivation than during insulin treatment. The percentage of KIC oxidized (leucine oxidation/transamination rate of leucine to $\mathrm{KIC}$ ) was, however, lower during insulin deprivation $(14.2 \pm 0.3 \%)$ than during insulin treatment $(35.3 \pm 6.1 \%, P<0.001)$ (Table VI).

Whole-body phenylalanine and tyrosine metabolism (Fig. $6)$. Whole-body phenylalanine flux $(45.3 \pm 1.4$ vs. $36.9 \pm 1.5$ $\mu \mathrm{mol} / \mathrm{kg} / \mathrm{h}, P<0.01)$ and tyrosine flux $(37.2 \pm 1.6$ vs. $29.1 \pm 1.1 \mu \mathrm{mol} / \mathrm{kg} / \mathrm{h}, P<0.01$ ) were higher during insulin deprivation than during insulin treatment. Also like leucine carbon flux, these two essential amino acid fluxes demonstrated that insulin treatment decreased whole-body protein breakdown. Phenylalanine conversion to tyrosine $(5.1 \pm 0.3$ vs. $4.6 \pm 0.3$ $\mu \mathrm{mol} / \mathrm{kg} / \mathrm{h}, \mathrm{NS}$ ) was not different in the two studies. Phenylala-
Table V. Amino Acid Balance across the Leg and Splanchnic Region in IDDM Patients ( $\mu \mathrm{mol} / \mathrm{min}$ )

\begin{tabular}{lccc}
\hline \multicolumn{1}{c}{ Amino acid } & Insulin deprived & Insulin treated & P value \\
\hline Across leg & & & \\
Aspartate & $0.32 \pm 0.17$ & $0.92 \pm 0.19$ & 0.027 \\
Glutamate & $5.35 \pm 0.91$ & $7.34 \pm 0.99$ & 0.057 \\
Serine & $-2.95 \pm 0.56$ & $2.74 \pm 0.68$ & 0.000 \\
Glutamine & $-36.65 \pm 12.90$ & $-10.74 \pm 2.66$ & 0.085 \\
Histidine & $-2.61 \pm 0.38$ & $-0.23 \pm 0.66$ & 0.021 \\
GLycine & $-8.60 \pm 0.47$ & $-3.04 \pm 1.65$ & 0.023 \\
Threonine & $-5.69 \pm 0.46$ & $-0.91 \pm 1.03$ & 0.008 \\
Alanine & $-23.24 \pm 1.70$ & $-9.57 \pm 1.64$ & 0.000 \\
Tyrosine & $-1.91 \pm 0.24$ & $-0.48 \pm 0.28$ & 0.020 \\
Valine & $-1.95 \pm 1.88$ & $-0.41 \pm 0.95$ & 0.089 \\
Methionine & $-1.76 \pm 0.22$ & $-0.65 \pm 0.25$ & 0.022 \\
Phenylalanine & $-2.90 \pm 0.60$ & $-0.48 \pm 0.22$ & 0.010 \\
Isoleucine & $-1.45 \pm 0.62$ & $-0.10 \pm 0.33$ & 0.013 \\
Leucine & $-2.29 \pm 0.13$ & $-0.17 \pm 0.77$ & 0.050 \\
Lysine & $-8.20 \pm 0.99$ & $-0.83 \pm 0.96$ & 0.001 \\
KIC & $-1.65 \pm 0.30$ & $-0.28 \pm 0.05$ & 0.010 \\
Across splanchnic region & & & \\
Aspartate & $-0.92 \pm 0.84$ & $-1.82 \pm 0.36$ & 0.297 \\
Glutamate & $-29.89 \pm 6.64$ & $-49.30 \pm 6.83$ & 0.104 \\
Serine & $36.29 \pm 4.31$ & $17.31 \pm 3.04$ & 0.001 \\
Glutamine & $93.77 \pm 16.78$ & $44.45 \pm 11.56$ & 0.095 \\
Histidine & $13.05 \pm 1.24$ & $5.68 \pm 1.02$ & 0.003 \\
Glycine & $32.84 \pm 4.67$ & $7.14 \pm 1.92$ & 0.017 \\
Threonine & $29.92 \pm 2.18$ & $12.19 \pm 1.86$ & 0.001 \\
Alanine & $127.74 \pm 9.11$ & $72.68 \pm 7.85$ & 0.019 \\
Tyrosine & $11.64 \pm 1.70$ & $8.94 \pm 2.41$ & 0.007 \\
Valine & $4.29 \pm 5.25$ & $2.06 \pm 2.12$ & 0.672 \\
Methionine & $8.36 \pm 0.67$ & $4.32 \pm 0.59$ & 0.015 \\
Phenylalanine & $12.96 \pm 2.00$ & $4.40 \pm 0.44$ & 0.005 \\
Isoleucine & $1.32 \pm 1.85$ & $-1.78 \pm 0.99$ & 0.277 \\
Leucine & $4.77 \pm 1.56$ & $0.46 \pm 1.80$ & 0.010 \\
Lysine & $39.05 \pm 5.17$ & $8.31 \pm 2.35$ & 0.004 \\
KIC & $3.80 \pm 1.40$ & $-0.20 \pm 0.50$ & 0.005
\end{tabular}

Note, leucine, KIC phenylalanine, and tyrosine concentrations were measured by a gas chromatograph/mass spectrometer using internal standards. All other amino acids were measured by HPLC.

nine incorporation into protein on protein synthesis (phenylalanine flux minus phenylalanine conversion to tyrosine) $(40.2 \pm 1.2$ vs. $32.3 \pm 1.3 \mu \mathrm{mol} / \mathrm{kg} / \mathrm{h}, P<0.01)$ was also higher during insulin deprivation than during insulin treatment, supporting the conclusion from the leucine data.

\section{Regional protein dynamics}

Leucine kinetics in the splanchnic region (Fig. 7). Protein breakdown (leucine appearance from protein) $(33.2 \pm 2.7 \mathrm{vs}$. $21.54 \pm 2.7 \mu \mathrm{mol} / \mathrm{min}, P<0.05$ ) and protein synthesis (leucine disappearance minus leucine oxidation and transamination) $(40.5 \pm 1.7$ vs. $21.9 \pm 1.8 \mu \mathrm{mol} / \mathrm{min}, P<0.01)$ were higher during insulin deprivation than during insulin treatment.

Leucine kinetics in the leg (Fig. 7). Protein breakdown (10.4 \pm 1.1 vs. $6 \pm 1.1 \mu \mathrm{mol} / \mathrm{min}, P<0.05$ ) was higher during insulin deprivation, whereas protein synthesis $(4.7 \pm 1$ vs. $5.5 \pm 0.9 \mu \mathrm{mol} / \mathrm{min}, \mathrm{NS}$ ) was not different in the two studies. 


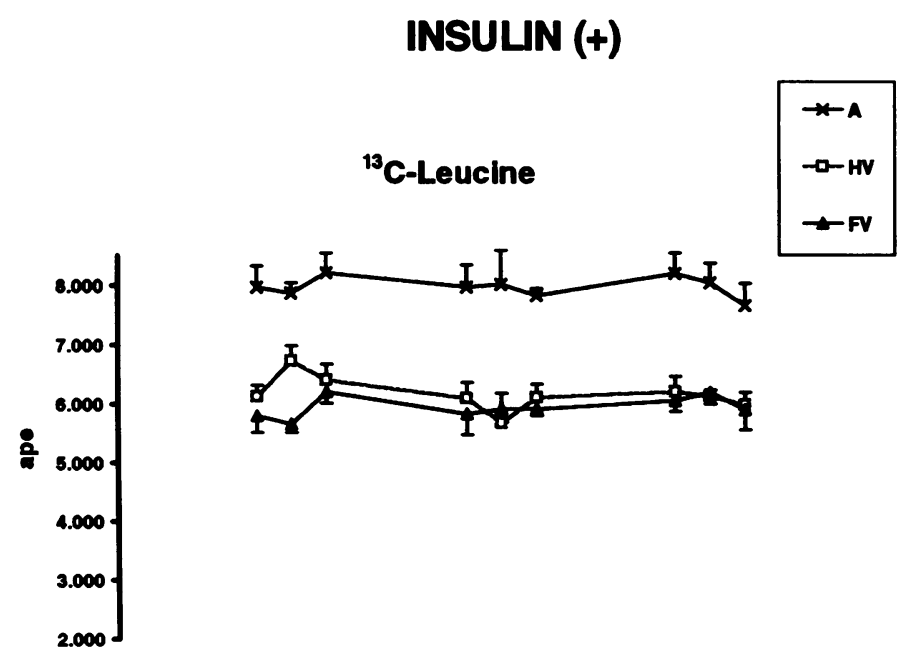

${ }^{13} \mathrm{C}-\mathrm{K} 1 \mathrm{C}$

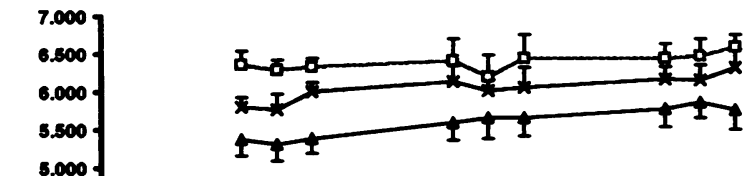

84.000

4.000

3.600

3.000

2.500

2.000

\section{INSULIN (-)}

${ }^{13}$ C-Leucine

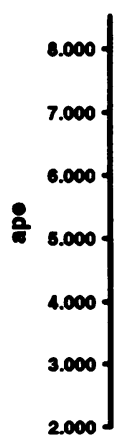

${ }^{13}$ C-KIC
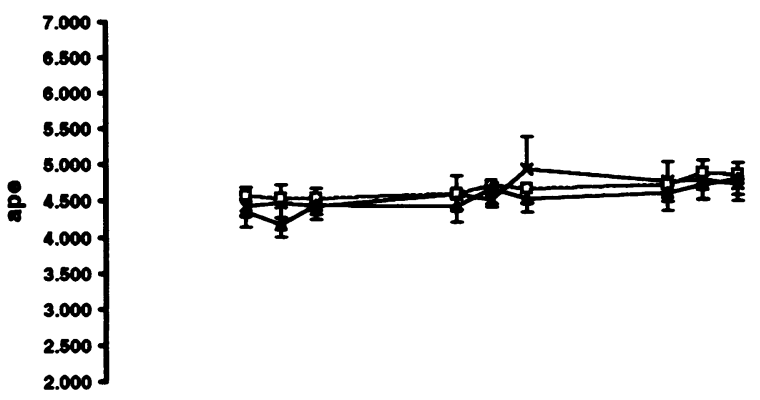

${ }^{13} \mathrm{CO}_{2}$

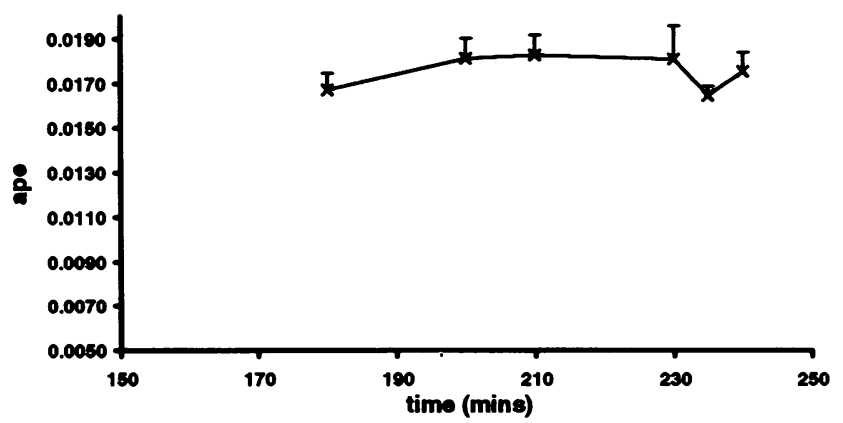

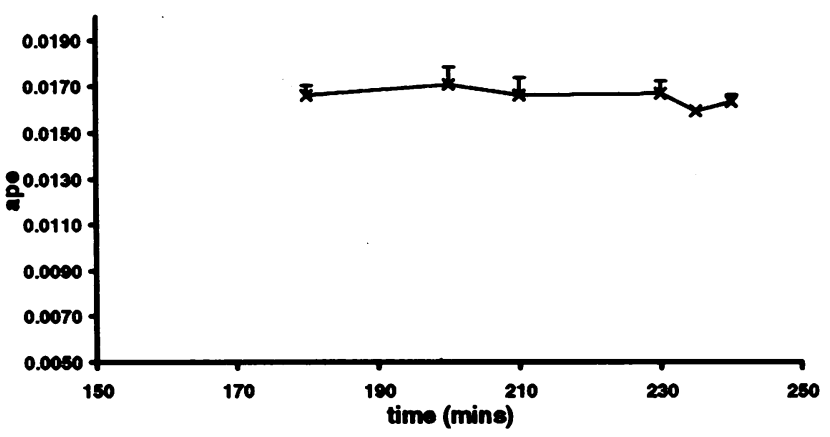

Figure 2. Isotopic plateau of $\left({ }^{13} \mathrm{C}\right)$ leucine, $\left({ }^{13} \mathrm{C}\right) \mathrm{KIC}$, and ${ }^{13} \mathrm{CO}_{2}$ during insulin treatment $(+)$ and insulin deprivation $(-)$.

Phenylalanine kinetics in the splanchnic region (Fig. 8). Phenylalanine appearance from protein (protein breakdown) $(15.8 \pm 1.2$ vs. $12.2 \pm 1.6 \mu \mathrm{mol} / \mathrm{min}, P<0.05)$ and phenylalanine incorporation into protein $(25.2 \pm 2.7$ vs. $14.2 \pm 1.8 \mu \mathrm{mol} /$ min, $P<0.01$ ) were higher during insulin deprivation than during insulin treatment. Phenylalanine conversion to tyrosine $(2.73 \pm 0.73$ vs. $2.88 \pm 0.86 \mu \mathrm{mol} / \mathrm{min}, \mathrm{NS})$ was not different in the two studies.

Phenylalanine kinetics across the leg (Fig. 8). Phenylalanine appearance rate from protein (protein breakdown) (5.0 \pm 0.7 vs. $3.2 \pm 0.5 \mu \mathrm{mol} / \mathrm{min}, P<0.05$ ) was higher during insulin deprivation than during insulin treatment. There was no difference in phenylalanine incorporation into protein $(2.46 \pm 0.6$ vs. $2.37 \pm 4)$ in the two studies.

\section{Discussion}

The most important finding from this study is that in IDDM patients, protein synthesis in the splanchnic region is elevated during insulin deprivation and this increase accounts for the entire increment in whole-body protein synthesis based on the phenylalanine model (Fig. 9) and for $82 \%$ based on the leucine 

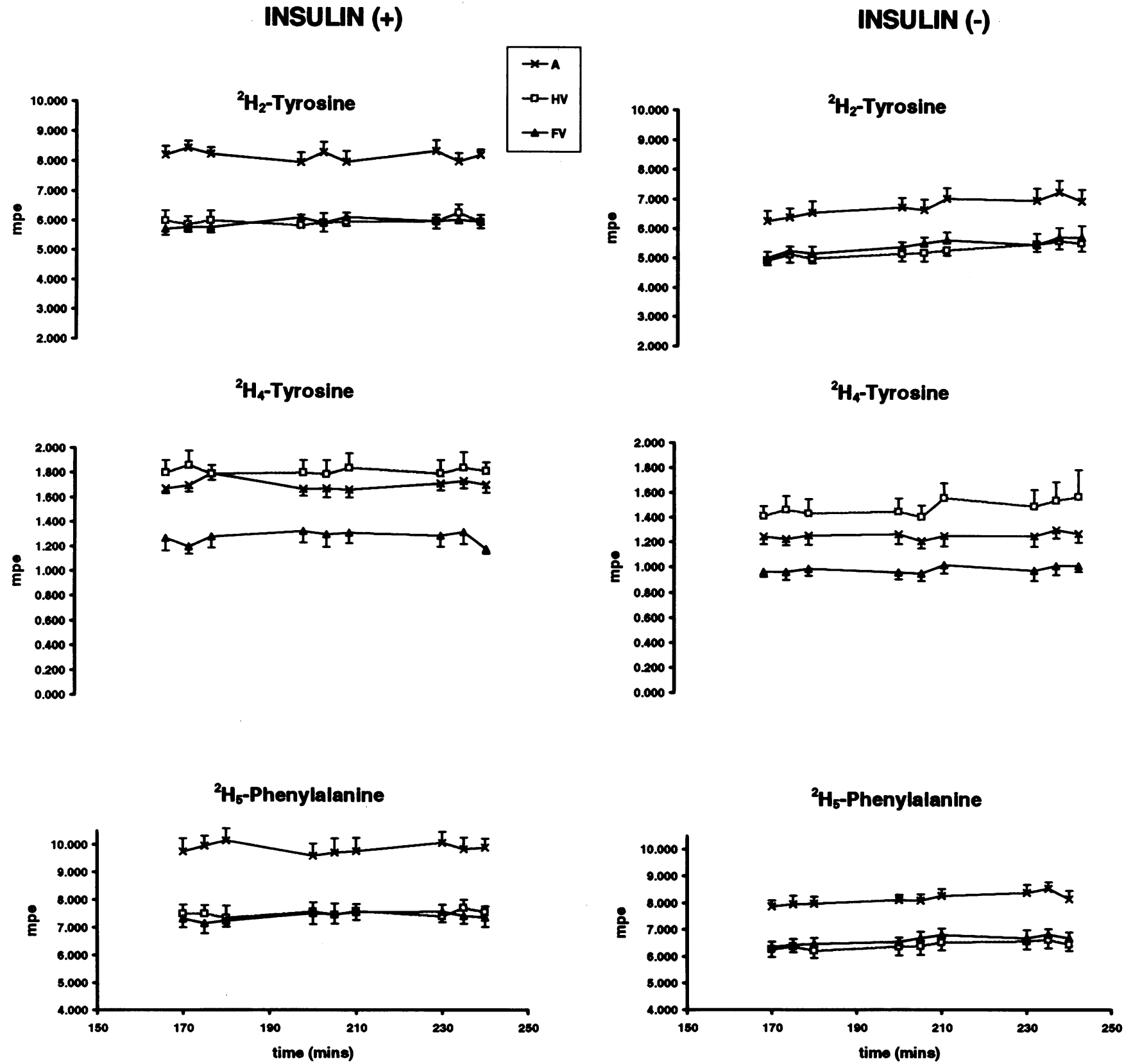

Figure 3. Isotopic plateau of $\left({ }^{2} \mathrm{H}_{2}\right)$ tyrosine $\left({ }^{2} \mathrm{H}_{4}\right)$ tyrosine, and $\left({ }^{2} \mathrm{H}_{5}\right)$ phenylalanine during insulin treatment $(+)$ and insulin deprivation $(-)$.

model. Whereas insulin reduced this elevated protein synthesis in the splanchnic region, it had no effect on protein synthesis in the leg (skeletal muscle). Insulin reduced protein breakdown not only in the splanchnic region, but also in the leg (skeletal muscle). The fall in protein breakdown in the splanchnic region occurred in conjunction with a fall in protein synthesis, such that it did not result in a net positive protein balance. The improvement of protein conservation by insulin appears to be entirely due to the fall in protein breakdown in skeletal muscle and in other tissues (exclusive of the splanchnic region). A substantial acceleration in leucine transamination was noted during the insulin-deprived state. We also confirmed the previously reported inhibition of the leucine oxidation rate by insulin. It was, however, noted that insulin increased the oxidation of KIC.
Two separate amino acid models were applied to study protein metabolism simultaneously in the whole body, as well as in the leg and splanchnic regions, in the diabetic patients. The leucine model was previously used in whole-body and forearm studies $(32,36)$, but here is applied for the first time in splanchnic studies. In addition, we used double-labeled leucine to study leucine $\mathrm{C}$ and $\mathrm{N}$ metabolism simultaneously in the leg and splanchnic regions in IDDM patients. The phenylalanine model has been previously used in forearm and leg studies in humans $(20,21,51)$. The application of the phenylalanine model is simpler in the leg, since the only fate of phenylalanine in the leg is its incorporation into protein. But unlike in the leg, phenylalanine is also converted to tyrosine in the liver. We therefore measured the conversion rate of phenylalanine to tyrosine in the splanchnic region, which allowed us to estimate phenylalanine 
INSULIN (+)

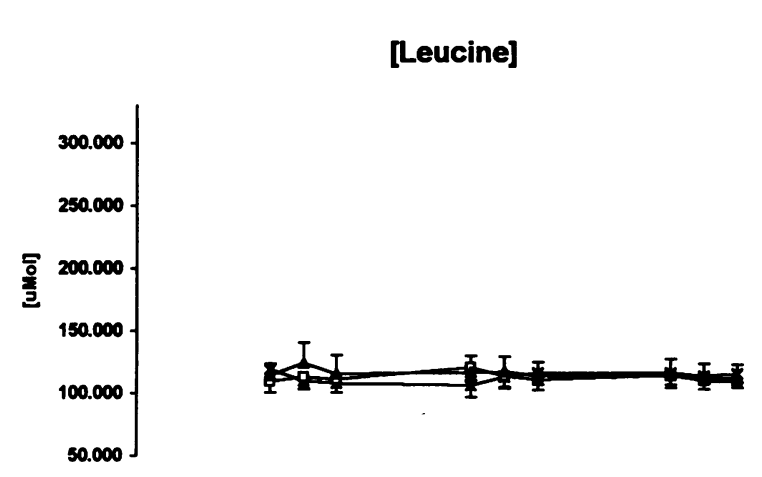

[KIC]

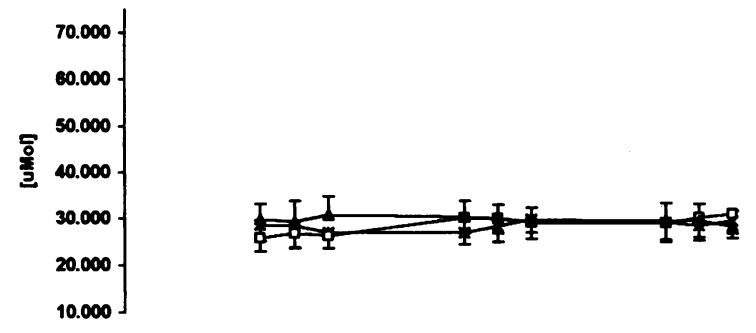

[Phenylalanine]
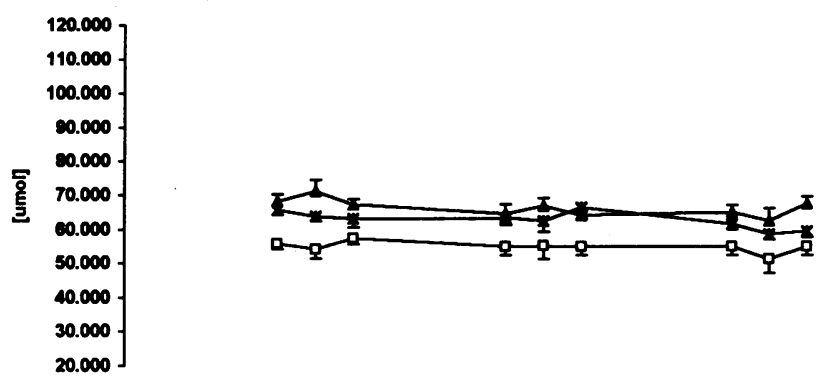

[Tyrosine]

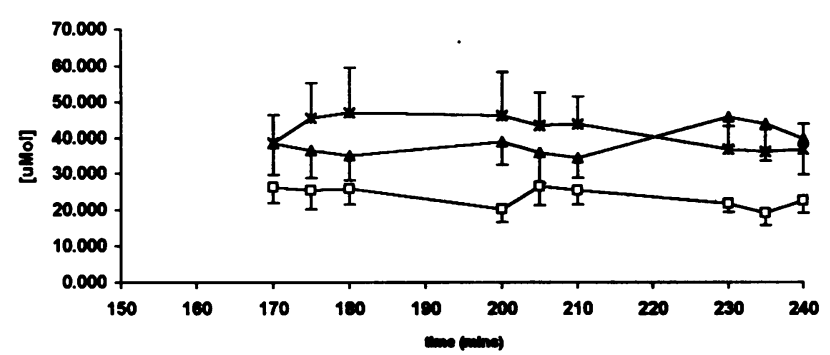

INSULIN (-)

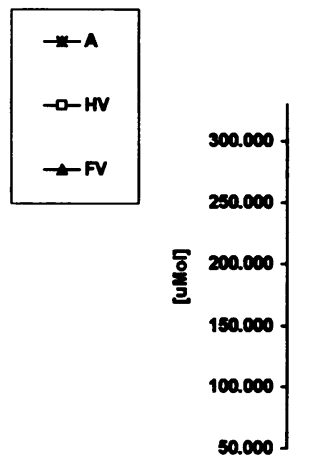

[Leucine]

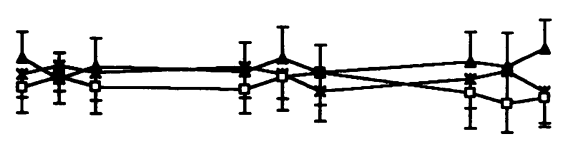

[KIC]
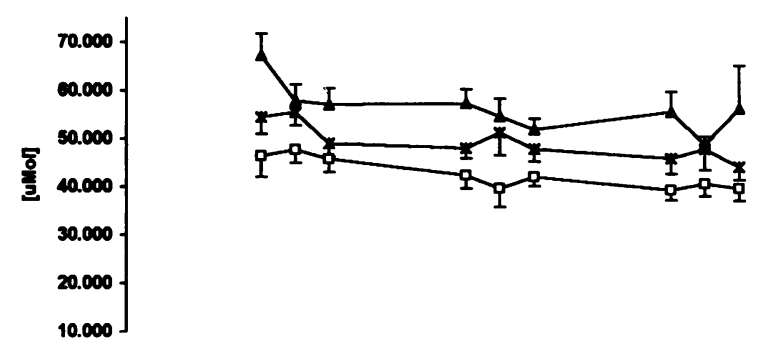

[Phenylalanine]
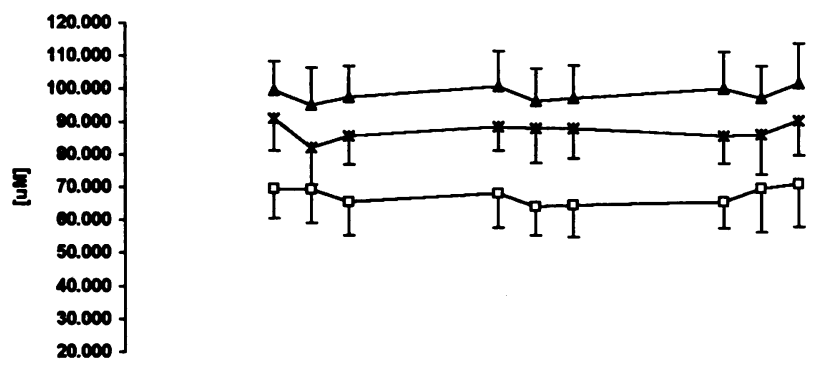

[Tyrosine]

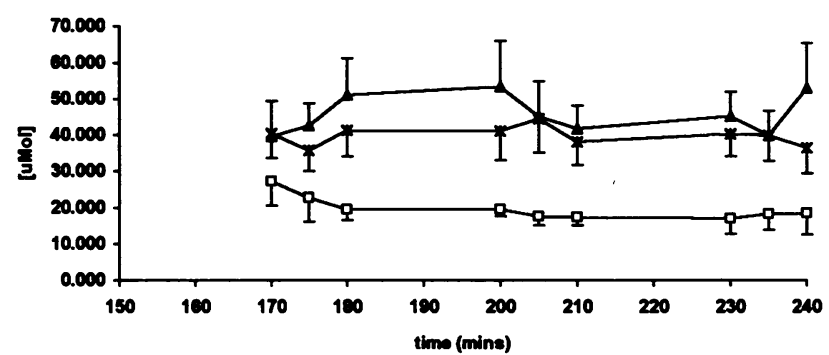

Figure 4. Plasma concentrations of leucine, KIC, phenylalanine, and tyrosine demonstrating steady state during insulin treatment $(+)$ and insulin deprivation $(-)$.

incorporation into protein. It is encouraging that the results from the two different models led us to the same conclusion regarding the mechanism of insulin's anticatabolic effect in IDDM pa- tients. This new approach of measuring protein dynamics simultaneously in two different regions along with the whole body can be applied in future studies. Since our knowledge about 


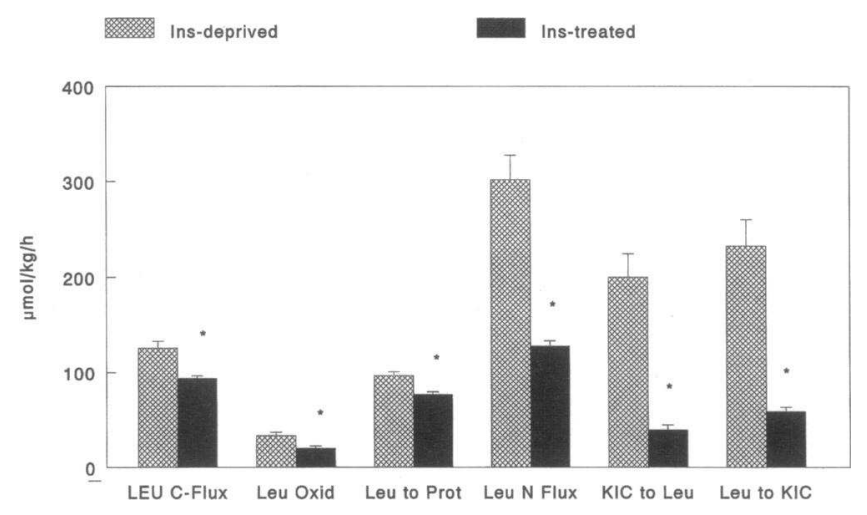

Figure 5. Whole-body leucine kinetics. Leucine carbon flux ( $L E U C$ Flux $)(P<0.05)$, leucine oxidation (Leu Oxid) $(P<0.05)$, leucine incorporation into protein (Leu to Prot) $(P<0.01)$, leucine nitrogen flux (Leu N Flux) $(P<0.001)$, KIC transamination from leucine (KIC to Leu) $(P<0.001)$, and leucine transamination from KIC (Leu to KIC) $(P<0.001)$ are all significantly higher during insulin treatment than during insulin deprivation.

protein metabolism in the splanchnic region is limited, this model may provide new insight into the regulation of protein turnover in humans.

The correct identification of the precursor pools for transamination, oxidation, and protein synthesis and the pool into which protein breakdown occurs is critical for the accuracy of the measurements reported in this paper. Since the immediate precursor of leucine oxidation is $\mathrm{KIC}$, we used $\mathrm{KIC}$ as the precursor of leucine oxidation measurements. For measurements of protein breakdown and leucine oxidation in a tissue, its intracellular isotopic enrichment should be ideally determined, which is not practical in human studies such as ours. All calculations across the tissue beds were performed using venous blood. This was based on an assumption that enrichment within venous blood more closely represents intracellular isotopic enrichment than that within arterial blood. This supposition is supported by studies in animals $(52,53)$ which show that venous isotopic enrichment closely approximates intracellular isotopic enrichments within the liver and muscle. A problem inherent to all human studies is the difficulty in measuring aminoacyl-tRNA (the obligatory precursor of protein synthesis [54]). We and others have used various surrogates of aminoacyl-tRNA as the precursor in the calculation of protein synthesis. Recent studies in a swine model indicated that isotopic enrichment of $\left[{ }^{2} \mathrm{H}_{5}\right]-$ phenylalanine in liver and skeletal muscle interstitial fluids is

Table VI. Relative Values of Leucine Metabolism

\begin{tabular}{lcc}
\hline \multicolumn{1}{c}{ Parameter } & Insulin deprived & Insulin treated \\
\hline $\begin{array}{l}\text { Percentage of leucine flux oxidized } \\
\left(C / Q_{\mathrm{C}}\right)\end{array}$ & $20.9 \pm 1.6$ & $18.1 \pm 2.4$ \\
$\begin{array}{l}\text { Percentage of KIC reaminated to } \\
\text { leucine }\left(X_{\mathrm{N}} / X_{\mathrm{O}}\right)\end{array}$ & $85.8 \pm 0.9$ & $64.8 \pm 6.1^{*}$ \\
$\begin{array}{l}\text { Percentage of KIC oxidized }\left(C / X_{\mathrm{O}}\right) \\
\text { (1) }\end{array}$ & $14.2 \pm 0.9$ & $35.3 \pm 6.1^{*}$
\end{tabular}

$C$, leucine oxidation; $Q_{\mathrm{C}}$, Leucine carbon flux; $x_{\mathrm{N}}$, transamination rate of KIC to leucine; $X_{\mathrm{O}}$, transamination rate of leucine to KIC. * Significantly different from insulin-deprived state.

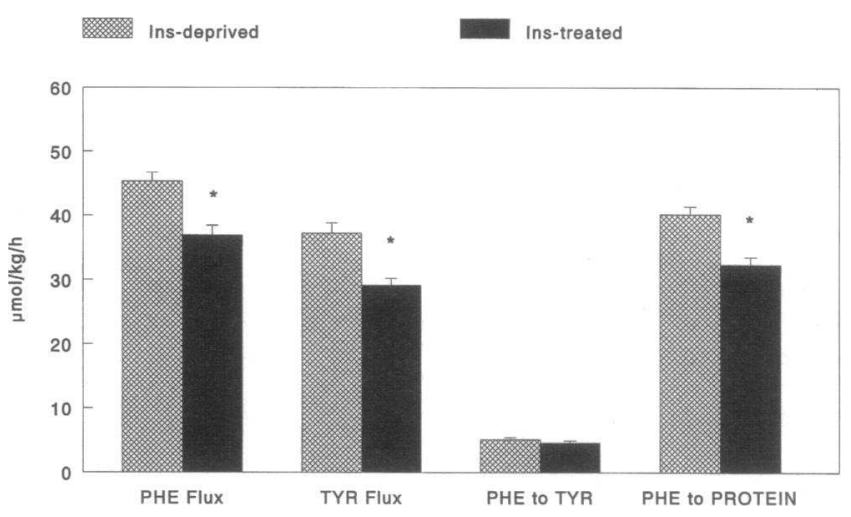

Figure 6. Whole-body phenylalanine and tyrosine kinetics. Phenylalanine flux (PHE Flux) $(P<0.01)$, phenylalanine incorporation into protein (PHE to PROTEIN) $(P<0.01)$, and tyrosine flux (TYR Flux) $(P<0.01)$ were significantly higher during insulin deprivation than during insulin treatment, whereas phenylalanine conversion to tyrosine (PHE to TYR) was not different.

not significantly different from the phenylalanyl-tRNA enrichment in the respective tissues (52). Similarly, our study (52) and that of Watt et al. (55) demonstrated that muscle leucyltRNA enrichment is closely approximated by plasma $\left({ }^{13} \mathrm{C}\right) \mathrm{KIC}$ enrichment and the enrichment within interstitial fluid obtained by muscle biopsy.

To our knowledge, this is the first time that protein synthesis and degradation rates in the splanchnic region of diabetic patients have been measured. In a previous study on normal subjects, $\mathrm{L}-\left(1-{ }^{14} \mathrm{C}\right)$ leucine was used to measure leucine kinetics in leg and splanchnic tissues (49). Animal studies indicated that in streptozotocin-induced diabetic rats, gut protein content increased whereas skeletal muscle protein content decreased (27, 28). This increase in gut protein may be related to hyperphagia, but the increase in gut protein content occurred in the presence of insulin deficiency in these animals. Gut protein synthesis was found to be relatively insensitive to insulin $(27,28)$. Insulin in short-term liver perfusion studies failed to stimulate hepatic

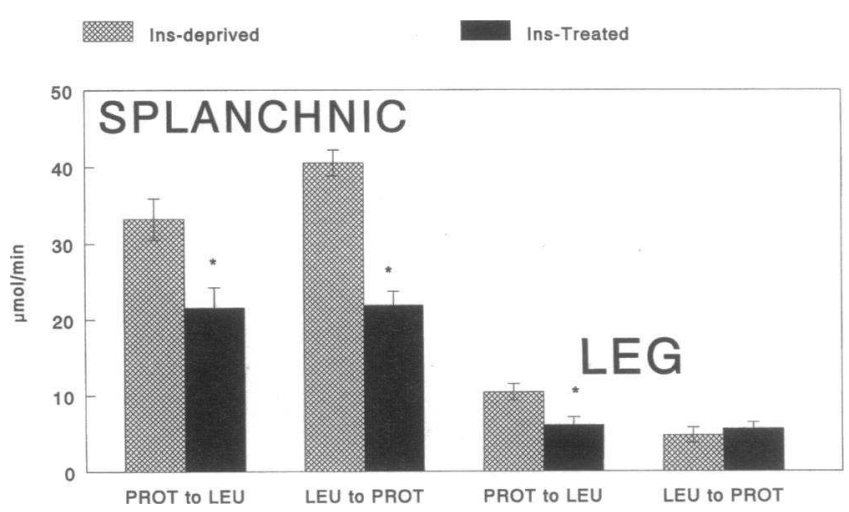

Figure 7. Regional leucine kinetics. In the splanchnic region, leucine appearance from protein breakdown (PROT to $L E U)(P<0.05)$ and leucine incorporation into proteins ( $L E U$ to PROT) $(P<0.01)$ were significantly higher during insulin treatment. In the leg, leucine appearance from protein breakdown (PROT to $L E U)(P<0.05)$ was significantly higher during insulin deprivation than during insulin treatment, but leucine incorporation into protein ( $L E U$ to PROT) was not different. 


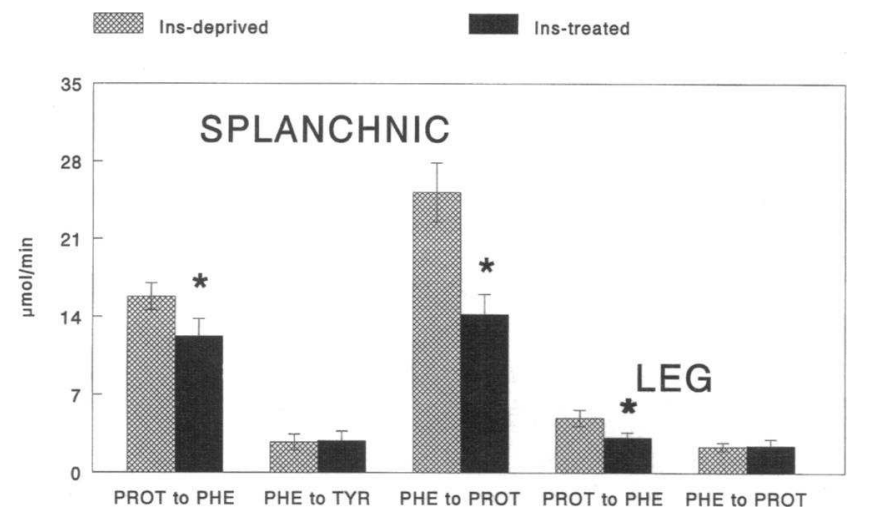

Figure 8. Phenylalanine kinetics across splanchnic and leg tissues $(P$ $<0.05$ ). Phenylalanine appearance from protein (PROT to PHE) in splanchnic and leg tissues was significantly higher during insulin deprivation than during insulin treatment, whereas phenylalanine incorporation into protein ( $P H E$ to PROT) was higher only in the splanchnic region during insulin deprivations. Phenylalanine conversion to tyrosine (PHE to TYR) was not different in the two studies.

protein synthesis $(56,57)$. Insulin also has been reported to stimulate albumin synthesis rate while inhibiting the synthesis rate of fibrinogen in humans (58) although another group found no such effect of insulin (59). Based on both animal and in vitro studies, it is reasonable to say that liver protein synthesis is also relatively insensitive to insulin. We therefore hypothesized that during the insulin-deficiency state, an increased amino acid availability due to protein breakdown stimulated protein synthesis primarily in insulin-insensitive tissues such as the gut and some proteins in the liver (18). The current results provide support for this hypothesis.

Both systemic (22) and intraarterial infusions of insulin $(20,21)$ have been shown to inhibit skeletal muscle protein breakdown in human. In some studies systemic infusion of insulin decreased whole-body protein breakdown but failed to decrease skeletal muscle protein breakdown $(13,23,24)$. The current study used much smaller doses of insulin than other studies. Unlike the previous studies, we only infused insulin sufficient to maintain euglycemia. Insulin at this concentration (12 $\mu \mathrm{U} / \mathrm{ml}$ ) was sufficient to cause a significant decrease in skeletal muscle protein breakdown. In fact, our study suggests that insulin's protein anabolic effect is largely due to its inhibition of protein breakdown in skelètal muscle. It has been shown that the maximal inhibitory effect of insulin on skeletal muscle protein breakdown in humans occurs at a low insulin concentration and that there is no dose-related fall in skeletal muscle protein breakdown (20). In our subjects, the fall in protein breakdown occurred with a small dose of insulin because our subjects were insulin deficient. An increase in insulin concentrations achieved by other studies may not have shown a decrease in skeletal muscle proteins breakdown because the maximal effect may have already been achieved by the circulating insulin concentration.

The current study further confirmed previous report by us $(15,18)$ and others $(17,20-22,60)$ that insulin does not stimulate skeletal muscle protein synthesis in the postabsorptive state. This finding continues to be in conflict with in vitro data and studies in streptozotocin-induced diabetic rats $(28,29,50)$. Both in vitro and animal studies demonstrated that insulin pro-

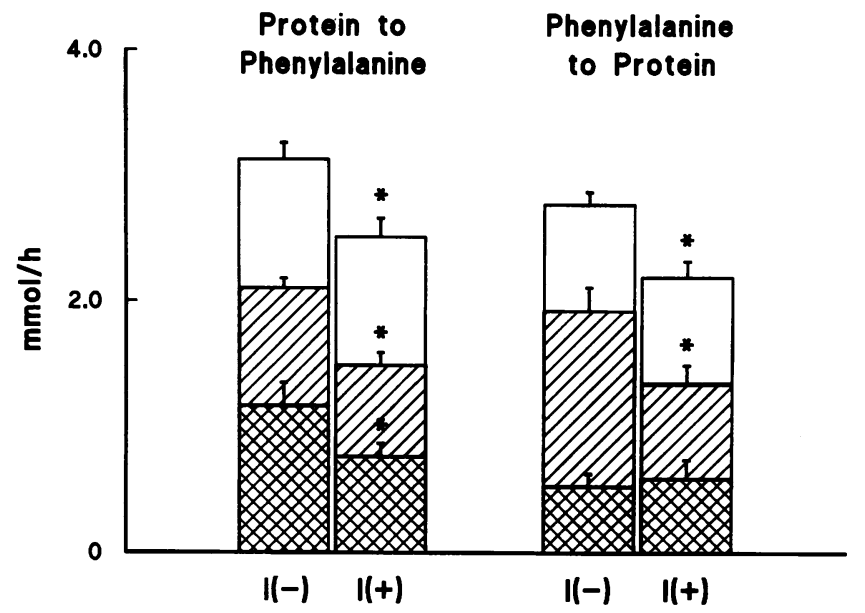

Figure 9. Changes in phenylalanine kinetics: contributions by splanchnic regions and skeletal muscle. Splanchnic region (घ) accounted for a similar proportion $(\sim 30 \%)$ of whole-body protein breakdown during insulin deprivation and insulin treatment. Skeletal muscle

(圈) accounted for $37 \%$ of whole-body protein breakdown during insulin deprivation, but for $30 \%$ during insulin treatment. The splanchnic region $(\nabla)$ accounted for $50 \%$ of whole-body protein synthesis during insulin deprivation, but only for $34 \%$ during insulin treatment. Skeletal muscle (图) contributed less (19\%) to whole-body protein synthesis during insulin deprivation than during insulin treatment $(27 \%)$. The entire change in whole-body protein synthesis is accounted for by changes in the splanchnic region $(\sim 600 \mu \mathrm{mol} / \mathrm{h})$. Whole-body skeletal muscle protein synthesis is estimated based on an assumption that one leg is $25 \%$ of whole-body skeletal muscle mass.

motes muscle protein synthesis $(26-29)$ probably by its effect at the posttranscriptional level $(26,27)$. Recently, it has been reported that the insulin-induced stimulation of muscle protein synthesis takes place only in growing rats and not in fully grown rats (50). It is possible that insulin may have a different effect in children with IDDM than in adult diabetic subjects. It was recently reported that in an 11-y-old girl with congenital lipodystrophy and diabetes, insulin stimulated whole-body protein synthesis in addition to reducing protein breakdown (61).

It has been hypothesized that the lack of effect of insulin on protein synthesis in the postabsorptive state is due to the reduced supply of amino acids (secondary to insulin-induced inhibition of protein breakdown) in the fasted human subjects $(8,10,18,24)$. Infusion of amino acids simultaneously with insulin has been reported to stimulate protein synthesis in some (14) but not in all studies $(17,62)$. Additional studies are needed to resolve these contradictory results.

Analysis of the phenylalanine data indicates that the change in whole-body protein synthesis $(\sim 600 \mu \mathrm{mol} / \mathrm{h})$ can be fully $(100 \%)$ accounted for by the changes within the splanchnic bed (Fig. 9). Based on the leucine model, $82 \%$ of the change in whole-body protein synthesis is accounted for by the splanchnic region. Insulin deprivation caused a net uptake of phenylalanine within the splanchnic bed, and a net release of phenylalanine from the leg. The latter indicates that insulin deprivation results in skeletal muscle but not splanchnic catabolism. In the insulindeprived state, using the phenylalanine model, splanchnic regions account for $50 \%$ of the whole-body protein synthesis rate, whereas skeletal muscle accounts for only $19 \%$. In the insulintreated state, splanchnic regions contribute only $34 \%$ to wholebody protein synthesis, whereas the skeletal muscle contribution 
increased to $27 \%$. This proportion of contribution by skeletal muscle to whole-body protein synthesis is similar to what has been observed in normal healthy subjects (18), whereas the observed contribution in the insulin-deprived state is lower than that in normal subjects. Leucine data also showed comparable changes. In the insulin-deprived state, increased uptake of amino acids (not only glycogenic, but also other amino acids) occurred in the splanchnic region presumably for protein synthesis. The increased flux of amino acids from skeletal muscle and other tissues might stimulate protein synthesis in splanchnic regions. This process helps to conserve amino acids in the insulin-deprived state and thus contributes to the survival of the patients during insulin deprivation.

A substantial increase in leucine transamination occurred during insulin deprivation. It is noteworthy that a higher percentage of $\mathrm{KIC}$ transaminated from leucine was oxidized during insulin treatment than during insulin deprivation (Table VI). The cause of enhanced transamination during insulin deprivation is unknown. One possibility is that of glucagon activation of branched-chain 2-oxo acid dehydrogenase (63). Against this, however, is the fact that glucagon receptors have not been demonstrated in skeletal muscle, in which there is a greater part of this enzyme activity.

In conclusion, this study demonstrated that increased protein synthesis occurs in the splanchnic bed during insulin deprivation and that this increased protein synthesis accounts for the increment of whole-body protein synthesis that occurs in insulindeprived IDDM patients. We also observed a substantial increase in leucine transamination during insulin deprivation, which is responsible for the increased KIC oxidation in these patients.

\section{Acknowledgments}

We are grateful to Ms. Valeri Houck, Mr. David Ebenstein, and Ms. Patricia Baumann for their technical assistance, the nursing and technical staff of the Clinical Physiology Department at Karolinska Hospital for their assistance, and Amy Wagner for secretarial assistance.

This work was supported by National Institutes of Health grants DK-41973 and RR-109.

\section{References}

1. Geyelin, H. R., G. Harrop, M. F. Murray, and E. Corwin. 1922. The use of insulin in juvenile diabetes. J. Metab. Res. 11:767-791.

2. Atchley, D. W., R. F. Loeb, D. W. Richards, E. I. M. Benedict, and M. E. Driscol. 1933. On diabetic acidosis: a detailed study of electrolyte balances following the withdrawal and reestablishment of insulin therapy. J. Clin. Invest. 12:297326.

3. Walsh, C. H., N. G. Soler, H. James, T. C. Harvey, B. J. Thomas, J. H Fremlin, M. G. Fitzgerald, and J. M. Malins. 1976. Studies in whole body potassium and whole body nitrogen in newly diagnosed diabetics. Quart. J. Med. 45:295-301.

4. Luck, J. M., G. Morrison, and L. F. Wilbur. 1928. The effect of insulin on the amino acid content of blood. J. Biol. Chem. 77:151-156.

5. Felig, P., J. Wahren, R. Sherwin, and G. Palaiologos. 1977. Amino acid and protein metabolism in diabetes. Arch. Intern. Med. 137:507-511.

6. Nair, K. S., D. Halliday, and J. S. Garrow. 1984. Increased energy expenditure in poorly controlled type I diabetic patients. Diabetologia. 27:13-16.

7. Nair, K. S., J. S. Garrow, C. Ford, R. F. Mahler, and D. Halliday. 1983. Effect of poor diabetic control and obesity on whole body protein metabolism in man. Diabetologia. 25:400-403.

8. Nair, K. S. 1984. Energy and protein metabolism in diabetes and obesity. PhD thesis. Council of National Academic Awards, London. 190 pp.

9. Robert, J. J., B. Beaufrere, J. Koziet, J. F. Desjeux, D. M. Bier, V. R. Young, and H. Lestradet. 1985. Whole body de novo amino acid synthesis in type I (insulin-dependent) diabetes studied with stable isotope-labeled leucine, alanine, and glycine. Diabetes. 34:67-73.
10. Nair, K. S., G. C. Ford, and D. Halliday. 1987. Effect of intravenous insulin treatment on in vivo whole body leucine kinetics and oxygen consumption in insulin-deprived type I diabetic patients. Metabolism. 36:491-495.

11. Umpleby, A. M., M. A. Boroujerdi, P. M. Brown, E. R. Carson, and D. H. Sonksen. 1988. The effect of metabolic control on leucine metabolism in type I (insulin-dependent) diabetic patients. Diabetologia. 28:131-141.

12. Tessari, P., R. Nosadini, R. Trevisan, S. V. De Krutzenberg, S. Inchiostro, E. Duner, G. Biolo, M. C. Marescotti, M. C. Tiengo, A. Tiengo, and G. Crepaldi. 1986. Defective suppression by insulin of leucine-carbon appearance and oxidation in type I, insulin-dependent diabetes mellitus. J. Clin. Invest. 177:17971804.

13. Tessari, P., G. Biolo, S. Inchiostro, L. Sacca, R. Nosadini, M. T. Boscarato, R. Trevisan, S. V. De Krutzenberg, and A. Tiengo. 1990. Effects of insulin on whole body and forearm leucine and KIC metabolism in type I diabetes. Am. J. Physiol. 259:E396-E103.

14. Luzi, L., P. Castellino, D. C. Simonson, A. S. Petrides, and R. A. DeFronzo. 1990. Leucine metabolism in IDDM: role of insulin and substrate availability. Diabetes. 39:38-48.

15. Pacy, P. J., K. S. Nair, C. Ford, and D. Halliday. 1989. Failure of insulin infusion to stimulate fractional muscle protein synthesis in type I diabetic patients. Diabetes. 38:618-624.

16. Pacy, P. J., G. N. Thompson, and D. Halliday. 1991. Measurement of whole-body protein turnover in type 1 diabetic patients: comparison of $\left({ }^{13} \mathrm{C}\right)$ leucine and $\left({ }^{2} \mathrm{H}_{5}\right)$ phenylalanine methodologies. Clin. Sci. (Oxf.). 80:245-252.

17. Bennet, W. M., A. A. Connacher, K. Smith, R. T. Jung, and M. J. Rennie. 1990. Inability to stimulate skeletal muscle or whole body protein synthesis in type I diabetes patients by insulin-plus-glucose during amino acid infusion: studies of incorporation and turnover of tracer $\mathrm{L}\left(1-{ }^{13} \mathrm{C}\right)$ leucine. Diabetologia. 33:433443.

18. Nair, K. S., and K. C. Copeland. 1992. Protein metabolism in type I diabetic patients. In Protein Metabolism or Diabetic Mellitus. K. S. Nair, editor. Smith-Gordan, London. 233-245.

19. Fukagawa, N. K., K. L. Minaker, J. W. Rowe, M. N. Goodman, D. E. Matthews, D. M. Bier V. R., and V. R. Young. 1985. Insulin mediated reduction of whole body protein breakdown: dose response effects of leucine metabolism in post absorptive man. J. Clin. Invest. 76:306-311.

20. Louard, R. M., D. A. Figburg, R. A. Gelfand, and E. J. Barrett. 1992. Insulin sensitivity of protein and glucose metabolism in human forearm skeletal muscle. J. Clin. Invest. 90:2348-2354.

21. Gelfand, R. A., and E. J. Barrett. 1988. Effect of physiologic hyperinsulinemia on skeletal muscle protein synthesis and breakdown in man. J. Clin. Invest. 80:1-6.

22. Dennie, S. C., Y. Liechty, Y. M. Liu, G. Brechtel, and A. D. Baron. 1991. Proteolysis in skeletal muscle and whole body in response to euglycemic hyperinsulinemia in normal adults. Am. J. Physiol. 261:E809-E814.

23. Heslin, M. J., E. Newman, R. F. Wolfe, P. W. T. Pister, and M. F. Brennan. 1992. Effect of hyperinsulinemia in whole body and skeletal muscle leucine kinetics in humans. Am. J. Physiol. 262:E911-E918.

24. Arfvidsson, B., H. Zachrisson, A.-C. Moller-Loswick, A. Hyltauder, R. Sandstrom, and K. Lundholm. 1991. Effect of systemic hyperinsulinemia on amino acid flux across human legs in postabsorptive state. Am. J. Physiol. 260:E46-E52.

25. Wahren, J., P. Felig, and L. Hagenfeldt. 1976. Effect of protein ingestion on splanchnic and leg metabolism in normal man and in patients with diabetes mellitus. J. Clin. Invest. 57:987-999.

26. Jefferson, L. S. 1980. Role of insulin in the regulation of protein synthesis. Diabetes. 29:487-496.

27. Proud, C. G. 1994. Turned on by insulin. Nature (Lond.). 371:747-748.

28. Pain, V. M., and P. J. Garlick 1974. Effect of streptozotocin diabetes and insulin treatment on the rate of protein synthesis in tissues of the rat in vivo. $J$. Biol. Chem. 249:4510-4514.

29. Pain, V. M., E. C. Albertse, and P. J. Garlick. 1983. Protein metabolism in skeletal muscle, diaphragm and heart of diabetic rats. Am. J. Physiol. 245:E604E610.

30. Hagenfeldt, L. S., S. Ericksson, and J. Wahren. 1980. Influence of leucine on arterial concentrations and regional exchange of amino acids in healthy subjects. Clin. Sci. (Oxf.). 59:173-181.

31. Zierler, K. L., and D. Rabinowitz. 1963. Role of insulin and growth hormone based on studies of forearm. Medicine. 42:385-402.

32. Matthews, D. E., D. M. Bier, M. J. Rennie, R. H. T. Edwards, D. Halliday, D. J. Millward, and G. A. Plugston. 1981. Regulation of leucine metabolism in man: a stable isotope study. Science (Wash. DC). 214:1129-1131.

33. Schwenk, W. F., P. J. Berg, B. Beaufrere, J. M. Miles, and M. W. Haymond. 1984. Use of $t$-butyl-dimethylsilylation in the gas chromatographic/mass spectrometric analysis of physiologic compounds found in plasma using electron impact ionization. Anal. Biochem. 141:101-109.

34. Thompson, G. N., P. J. Pacy, H. Merritt, G. C. Ford, M. A. Read, K. N. Cheng, and D. Halliday. 1989. Rapid measurement of whole body and forearm protein turnover using $\left[{ }^{2} \mathrm{H}_{5}\right]$ phenylalanine model. Am. J. Physiol. 256:E631E639. 
35. Ford, G. C., K. N. Cheng, and D. Halliday. 1985. Analysis of $\left(1-{ }^{13} \mathrm{C}\right)$ leucine and $\left({ }^{13} \mathrm{C}\right) \mathrm{KIC}$ in plasma by capillary gas chromatography/mass spectrometry in protein turnover studies. Biomed. Mass. Spec. 12:432-436.

36. Cheng, K. N., F. Dworzak, G. C. Ford, M. J. Rennie, and D. Halliday. 1985. Direct determination of leucine metabolism and protein breakdown in humans using $\mathrm{L}\left(1-{ }^{13} \mathrm{C},{ }^{15} \mathrm{~N}\right)$ leucine and forearm model. Eur. J. Clin. Invest. 15:345353.

37. Jones, B., and J. Gilligan. 1983. Amino acid analysis by $O$-pthaldehyde precolumn derivitization and reversed phase HPLC. Am. Biotechnol. Lab. 12:4551

38. Hohorst, H. J. 1962. Methoden der enzymatishchen Analyse. H. U. Bergmeyer, editor. Verlag Chemie, Weinheim. 266-270.

39. Miles, J., R. A. J. Aikens, J. Gerich, and M. Haymond. 1993. A microfluorometric method for the determination of free fatty acids in plasma. J. Lipid Res. 24:96-99.

40. Williamson, D. H., and J. Mellanby. 1974. Methods of Enzymatic Analysis. Vol. 4. H. U. Bergmeyer, editor. Academic Press, Inc., New London. 18361843.

41. Arnqvist, H., P. O. Olsson, and H. von Shenck. 1987. Free and total insulin determined after precipitation with polyethylene glycol: analytical characteristics and effects of sample handling and storage. Clin. Chem. 33:93-96.

42. Harris, W., G. R. Faloona, and R. H. Unger. 1979. Glucagon. In Methods of Hormone Radioimmunoassay. B. M. Jaffee and H. R. Behrman, editors. Academic Press, Inc., New York. 643-655.

43. Baumann, G. 1990. Growth hormone binding proteins and various forms of growth hormone: implications for measurements. Acta Pediatr. Scand. 370(Suppl.):72-80.

44. Bang, P., U. Eriksson, V. Sara, I. L. Wivall, and K. Hall. 1991. Comparison of acid ethanol extraction and acid gel filtration prior to IGF-I and IGF-II radioimmunoassays: improvement of determination in acid ethanol extracts by use of truncated IGF-I as radioligand. Acta Endocrinol. (Copenh.). 124:620-629.

45. Povoa, G., A. Roovete, and K. Hall. 1984. Crossreaction of serum somatomedin-binding protein in a radioimmunoassay developed for somatomedin-binding protein isolated from human amniotic fluid. Acta Endocrinol. (Copenh.) 107:563-570.

46. Hjemdahl, P., M. Daleskog, and T. Kahan. 1979. Determination of plasma catecholamines by high performance liquid chromatography with electrochemica detection: comparison with radioenzymatic method. Life Sci. 25:131-138.

47. Wolfe, R. R., R. D. Goodenough, M. H. Wolfe, G. T. Royle, and E. R. Nadel. 1982. Isotopic analysis of leucine and urea metabolism in exercising humans. J. Appl. Physiol. 52:458-466.

48. Jefferson, L. S., J. B. Li, and S. R. Rannels. 1977. Regulation by insulin of amino acid release and protein turnover in the perfused rat hemicorpus. J. Biol Chem. 252:1476-1483.

49. Gelfand, R. A., M. G. Glickman, P. Castellino, R. J. Louard, and R. A.
DeFronzo. 1988. Measurement of $\mathrm{L}\left[1^{14} \mathrm{C}\right]$ leucine kinetics in splanchnic and leg tissues in humans. Diabetes. 37:1364-1372.

50. Baillie, A. G. S., and P. J. Garlick. 1991. Attenuated responses of muscle protein synthesis to fasting and insulin in adult female rats. Am. J. Physiol. 262:E1-E5.

51. Nair, K. S., R. G. Schwartz, and S. Welle. 1987. Leucine as a regulator of whole body and skeletal muscle protein metabolism in humans. Am. J. Physiol. 263:E928-E931.

52. Baumann, P. Q., W. S. Stirewalt, B. D. O'Rourke, D. Howard, and K. S. Nair. 1994. Precursor pool of protein synthesis: a stable isotope study in a swine model. Am. J. Physiol. 267:E203-E209.

53. Layman, D. K., and R. R. Wolfe. 1987. Sample site selection for tracer studies applying a unidirectional circulatory approach. Am. J. Physiol. 253:E173E178.

54. Schneible, P. A., J. Airhart, and R. B. Low. 1981. Differential compartmentation of leucine for oxidation and for protein synthesis in cultured skeletal muscle J. Biol. Chem. 256:4888-4894.

55. Watt, P. W., Y. Lindsay, C. M. Scrimgeour, P. A. F. Chien, J. N. A. Gibson, D. J. Taylor, and M. J. Rennie. 1991. Isolation of aminoacyl-tRNA and its labeling with stable-isotope tracers: use in studies of human tissue protein synthesis. Proc. Natl. Acad. Sci. USA. 88:5892-5896.

56. Jefferson, L. S., J. W. Robertson, and C. M. Schworer. 1973. Effects of insulin and diabetes on hepatic protein turnover. Diabetes. 22:321-327.

57. Mortimore, G. E., and C. E. Mondon. 1970. Inhibition by insulin of valine turnover in liver. J. Biol. Chem. 245:2375-2383.

58. DeFeo, P., M. G. Gaisamo, and M. W. Haymond. 1991. Differential effects of insulin deficiency on albumin and fibrinogen synthesis in humans. J. Clin. Invest. 88:833-840.

59. Pacy, P. J., M. Read, and D. Halliday. 1990. Influence of insulin on albumin and non-albumin protein fractional synthetic rates in post-absorptive type I diabetic patients. Eur. J. Clin. Nutr. 44:343-349.

60. McNurlan, M. A., P. Essen, A. Thorell, A. G. Calder, S. E. Anderson, O. Ljunqvist, A. Sandgren, I. Grant, I. Tjader, P. E. Ballmer, J. Wernerman, and P. Garlick. 1994. Response of protein synthesis in human skeletal muscle to insulin: an investigation with $\left.\mathrm{L}^{2}{ }^{2} \mathrm{H}_{5}\right]$ phenylalanine. Am. J. Physiol. 267:E102-E108.

61. Copeland, K. C., K. S. Nair, P. B. Kaplowitz, D. C. Robbins, and J. Calles-Escandon. 1993. Discordant metabolic actions of insulin in extreme lipodystrophy of childhood. J. Clin. Endocrinol. Metab. 77:1240-1245.

62. Flakoll, P. J., M. Kulayat, M. Frexes-Steed, H. Hourani, L. L. Brown, J. O. Hull, and N. N. Abumrad. 1989. Amino acids augment insulin's suppression of whole body proteolysis. Am. J. Physiol. 257:E847.

63. Block, K. P., B. W. Haywood, M. G. Buse, and A. E. Harper. 1985. Activation of rat liver branched-chain 2-oxo-acid dehydrogenase in vivo by glucagon and adrenaline. Biochem. J. 232:593-597.

64. McNurlan, M. A., and P. J. Garlick. 1981. Protein synthesis in liver and small intestine in protein deprivation and diabetes. Am. J. Physiol. 241:E238E245. 